\title{
Coronaviruses: A Comparative Review
}

\author{
Kenneth McIntosh
}

With 13 Figures

Table of Contents

I. Introduction . . . . . . . . . . . . . . . . . . . . 86

II. Brief History and Clinical Aspects of Coronavirus Infections . . . . . . . 86

A. Infectious Bronchitis Virus . . . . . . . . . . . . . . . . . . . . 88

B. Mouse Hepatitis Virus . . . . . . . . . . . . . . . . . . . . . . . 90

C. Human Coronavirus Strains . . . . . . . . . . . . . . . . . . . 91

D. Transmissible Gastroenteritis Virus of Swine . . . . . . . . . . . . . 92

E. Hemagglutinating Encephalomyelitis Virus. . . . . . . . . . . . . . 93

F. Rat Coronavirus . . . . . . . . . . . . . . . . . . . 93

G. Sialodacryoadenitis Virus . . . . . . . . . . . . . . . . . . . . . 93

H. Summary . . . . . . . . . . . . . . . . . . . . . . . . . . . . 93

III. Properties of Coronaviruses . . . . . . . . . . . . . . . . . . . . . . 94

A. Morphology of the Virion . . . . . . . . . . . . . . . . . . . . 94

1. Negative Staining . . . . . . . . . . . . . . . . . . 94

2. Ultra-thin Sections . . . . . . . . . . . . . . . . . . . . . . . 99

B. Physical and Chemical Characteristics of Coronaviruses . . . . . . . . 102

1. Nature of the Nucleic Acid . . . . . . . . . . . . . . . . . . . 102

2. Sensitivity to Lipid Solvents . . . . . . . . . . . . . . . . . 103

3. Sensitivity to Physical Agents: Heat and Acid . . . . . . . . . . . 103

4. Chemical Composition of the Virion . . . . . . . . . . . . . . 105

5. Buoyant Density of the Virion . . . . . . . . . . . . . . . . 106

IV. Coronaviruses in Infected Cells. . . . . . . . . . . . . . . . . . . . . 106

A. Growth of Coronaviruses in Cell Monolayers and Laboratory Animals . . 106

B. Intracellular Development of Coronaviruses . . . . . . . . . . . . . 110

1. Fluorescent Antibody Studies . . . . . . . . . . . . . . . . . 110

2. Electron Microscopic Studies . . . . . . . . . . . . . . . 110

3. Single-Cycle Growth Curves . . . . . . . . . . . . . . . . . . . 112

V. Immunologic Studies . . . . . . . . . . . . . . . . . . . . . . . . . 113

A. Virus-Specific Antigens from Coronavirus Infected Cells . . . . . . . . 113

B. Hemagglutination . . . . . . . . . . . . . . . . . . . . . . 114

C. Complement Fixation . . . . . . . . . . . . . . . . . . . . 115

D. Serologic Interrelationships Among Coronaviruses . . . . . . . . . 116

VI. Summary . . . . . . . . . . . . . . . . . . . . . . . . . 118

References . . . . . . . . . . . . . . . . . . . . . 119 


\section{Introduction}

The coronaviruses have been recently classified as a separate virus genus on the basis of several fundamental characteristics, which include their nucleic acid type, the presence of a lipid envelope, and, in particular, their distinctive morphology (TYrReLi et al., 1968a). Members of the genus infect a number of different animal species, and until their reclassification were considered to belong to the myxovirus group although they possessed many atypical features. It was through detailed studies of their morphology in negatively stained preparations that they were finally differentiated and set out as a separate genus. When properly prepared, coronavirus particles appear medium-sized, round, and moderately pleomorphic, and bear characteristic widely-spaced club-shaped surface projections. Coronaviruses naturally infect man, chickens, pigs, mice and rats, causing a wide variety of disorders involving a number of different organ systems. Indeed, new species are being added at frequent intervals as the techniques of electron microscopy and modern virology are applied to diseases which have often been clinically recognized for decades. A tentative scheme of the coronavirus genus is shown in Table 1, with a listing of serotypes and strains. The list of types is not complete, but those of importance to this review are shown.

In spite of the wide distribution of coronaviruses in nature, information about their structure, their composition, and the events occurring in infected cells is limited. Until very recently, research into the nature of these organism has of necessity emphasized the highly pragmatic aspects of disease control, rather than more basic concepts of virus structure and function. On the other hand, it now appears clear that more fundamental knowledge is necessary not only for the advancement of science itself, but also for the achievement of many of the desired goals of treatment and control.

It will be the aim of this review to introduce the clinical aspects of coronavirus infections, to discuss the comparative biology of all recognized members of the coronavirus genus and to suggest, by both inference and direct allusion, areas where future investigation may yield useful information. The review is by no means exhaustive, and the reader is referred at intervals to more detailed publications concerning individual species.

\section{Brief History and Clinical Aspects of Coronavirus Infections}

\section{A. Infectious Bronchitis Virus}

Infectious bronchitis virus (IBV) is the cause of a common and highly contagious acute respiratory disease of chickens known as avian infectious bronchitis. The disease was recognized as a separate clinical entity as early as 1931 by SCHALK and Hawn (1931), and the responsible agent was first grown in embryonated hens' eggs by Beaudette and Hudson in 1937 (1937). The disease in chickens is characterized by acute respiratory distress, tracheal rales and cough, a precipitous drop in egg production, a deterioration of egg 
Table 1. A tentative scheme of the coronavirus genus with a partial list of types and strains

\begin{tabular}{|c|c|c|c|c|}
\hline $\begin{array}{l}\text { Coronavirus } \\
\text { species }\end{array}$ & $\begin{array}{l}\text { Animal } \\
\text { host }\end{array}$ & $\begin{array}{l}\text { Coronavirus } \\
\text { serotypes }\end{array}$ & $\begin{array}{l}\text { Coronavirus } \\
\text { subtypes or } \\
\text { strains (if } \\
\text { applicable) }\end{array}$ & Original description \\
\hline $\begin{array}{l}\text { Infectious } \\
\text { bronchitis } \\
\text { virus } \\
\quad \text { (IBV) }\end{array}$ & chicken & $\begin{array}{l}\text { Massachusetts } \\
\text { Connecticut } \\
\text { Iowa-97 } \\
\text { Iowa-609 } \\
\text { Gray } \\
\text { Holte } \\
\text { Clark-333 } \\
\text { others }\end{array}$ & $\begin{array}{l}\text { IBV-41 } \\
\text { Beaudette } \\
\text { IBV-F } \\
\text { IBV-46 }\end{array}$ & 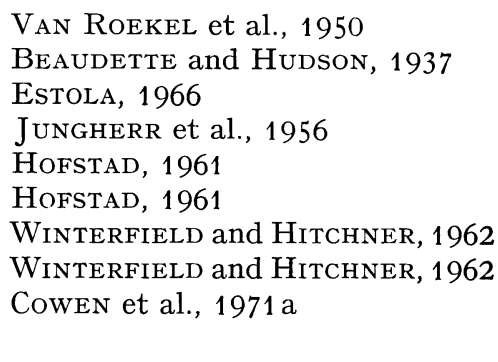 \\
\hline $\begin{array}{l}\text { Mouse } \\
\text { hepatitis } \\
\text { virus } \\
\quad(\mathrm{MHV})\end{array}$ & mouse & $\begin{array}{l}\text { JHM } \\
\text { MHV-1 } \\
\text { MHV (PRI) } \\
\text { MHV-3 } \\
\text { A-59 } \\
\text { others }\end{array}$ & $\begin{array}{l}\text { (subtypes and } \\
\text { strains not } \\
\text { described) }\end{array}$ & $\begin{array}{l}\text { ChEEVER et al., } 1949 \\
\text { GLEDHill et al., } 1951 \\
\text { Nelson, } 1952 \\
\text { DiCK et al., } 1956 \\
\text { MANAKER et al., } 1961\end{array}$ \\
\hline $\begin{array}{l}\text { Human } \\
\text { coronavirus } \\
\quad(\mathrm{HCV})\end{array}$ & $\operatorname{man}$ & $\begin{array}{l}229 \mathrm{E} \\
\mathrm{B} 814 \\
\text { OC } 43 \\
\text { others }\end{array}$ & $\begin{array}{l}229 \mathrm{E} \\
\text { LP } \\
489 \\
\\
\text { OC } 43 \\
\text { OC } 38\end{array}$ & $\begin{array}{l}\text { HAMRE and PROCKNOW, } 1966 \\
\text { TYRRELL et al., } 1968 \mathrm{~b} \\
\text { KAPIKIAN et al., } 1969 \\
\text { KENDALL et al., 1962; } \\
\text { TYRRELL and BYNOE, } 1965 \\
\text { McINTOSH et al., 1967 b } \\
\text { MCINTOSH et al., 1967 b }\end{array}$ \\
\hline $\begin{array}{l}\text { Transmissible } \\
\text { gastroenteritis } \\
\text { virus } \\
\quad(\mathrm{TGEV})\end{array}$ & pig & $\begin{array}{l}\text { (all are } \\
\text { antigenically } \\
\text { inseparable) }\end{array}$ & $\begin{array}{l}\text { Purdue } \\
\text { New York II } \\
\text { SH } \\
\text { FS } 216 / 64 \\
\text { TO } \\
\text { others }\end{array}$ & $\begin{array}{l}\text { Doyle and Hutchings, } 1946 \\
\text { LEE et al., } 1954 \\
\text { SASAHARA et al., } 1958 \\
\text { CARTWRIGHT et al., } 1964 \\
\text { HARADA et al., } 1967\end{array}$ \\
\hline $\begin{array}{l}\text { Hemagglutinating } \\
\text { encephalomyelitis } \\
\text { virus (vomiting } \\
\text { and wasting } \\
\text { disease virus) } \\
\quad \text { (HEV) }\end{array}$ & pig & $\begin{array}{l}\text { (all are } \\
\text { probably } \\
\text { antigenically } \\
\text { inseparable) }\end{array}$ & $\begin{array}{l}\mathrm{HEV}-1 \\
2063 / 68 \\
67 \mathrm{~N}\end{array}$ & $\begin{array}{l}\text { GREig et al., } 1962 \\
\text { CARTwRIGHT and LuCAS, } 1970 \\
\text { MENGELING et al., } 1972\end{array}$ \\
\hline $\begin{array}{l}\text { Rat coronavirus } \\
\text { (RCV) }\end{array}$ & rat & $\begin{array}{l}\text { only one strain } \\
\text { characterized }\end{array}$ & 8190 & PARKER et al., 1970 \\
\hline $\begin{array}{l}\text { Sialodacryoadenitis } \\
\text { virus } \\
\quad(\mathrm{SDAV})\end{array}$ & rat & $\begin{array}{l}\text { only one strain } \\
\text { characterized }\end{array}$ & 681 & Bhatt et al., 1972 \\
\hline
\end{tabular}

quality by laying flocks (MCDougaLL, 1968), and a high mortality in young chicks. More recently, strains of IBV have been recovered from chickens suffering from nephrosis and uremia (Winterfield and Hitchner, 1962; 
Hirai and Shimakura, 1971). It thus appears that disease affects many different organs, including the upper and lower respiratory tract, the genital tract, and the urinary tract. At various times during infection, virus can be recovered from lung, spleen, cecal tonsil and kidney (Cook, 1968; HofsTAD and YODER, 1966). In well isolated chickens, infection persists in the trachea for 4 weeks (Cook, 1968). In flocks under field conditions, virus may persist for longer periods (HofSTAD, 1947; Cook, 1968). Immunity is probably passed to the young through antibodies in the yolk sac, and offspring of immune hens can be expected to retain some resistance to disease for several weeks (JUNGHERR and TERRELL. 1948),

The diagnosis may be made serologically, using the neutralization test (FABRICANT, 1951), a test for precipitating antibody (WitTER, 1962; WoERnLE, 1966), or an indirect hemagglutination test (BRown et al., 1962; MoHanty et al., 1964b). The presence of virus in infected chickens can be determined by direct fluorescent antibody staining of cells in the tracheal epithelium (Biтo et al., 1971; BRAUNE and GENTRY, 1965), and by recovery of the virus in embryonated eggs. The characteristic effect of IBV on chicken embryos, stunting and urate deposition in the kidneys and ureters, is often not seen for several egg passages. On the other hand, staining of cells in the allantoic fluid with fluorescent antibody (CLARKE et al., 1972) and direct electron microscopy of allantoic fluids to detect characteristic coronavirus particles after one or two passages (Marsolais et al., 1971; McFerRan et al., 1971) have been recently used for the rapid and specific diagnosis of IBV infection.

Significant disease in poultry flocks occurs worldwide (Kumar, 1971; Estola, 1966; Berry and Stokes, 1968; Stephens and Simmons, 1968), and attempts at control by means of vaccines have met with only limited success. The existence of multipie serotypes has been at least one factor obstructing adequate prophylaxis.

Much of the research in avian infectious bronchitis has been performed with the Beaudette strain (IBV-42), which is serologically similar to the Massachusetts serotype but has been adapted through multiple passages in the embryonated egg to the point that it rapidly kills chick embryos (which other strains of IBV do not) and has lost its infectivity for older chickens. It is not clear whether this virus strain has altered in other more fundamental properties, but this possibility must be kept in mind by those using it for research.

A comprehensive review of avian infectious bronchitis and infectious bronchitis virus has been recently published (Cunningham, 1970). For clinical aspects of the disease, the reader is referred to the chapter by HoFSTAD in Diseases of Poultry by Biester and Schwarte (Hofstad, 1965).

\section{B. Mouse Hepatitis Virus}

Modern small animal laboratory research has necessitated the breeding of large numbers of rodents in closed colonies. Murine viruses of low or moderate 
pathogenicity have proliferated under these epizootiologic circumstances, often going unnoticed because they could be perpetuated as asymptomatic infections in colonies with a high prevalence of antibody. When "virgin" mouse strains were introduced into such colonies, or when some other stress was added, mortality rates suddenly became high. Murine hepatitis due to mouse hepatitis virus (MHV) was first recognized in a closed mouse colony by GLEDHILl and ANDREwes (1951). In this instance, combined infection with an otherwise harmless murine protozoon, Eperythrozoon coccoides, and MHV led to fatal hepatitis in mice (GLedHILl et al., 1952; Niven et al., 1952).

Several years earlier a virus which caused encephalitis in mice had been isolated by CheEver et al., (1949). This virus, JHM strain, was subsequently shown to be antigenically related to the viruses discovered by GLEDHILL (Morris, 1959; Calisher and Rowe, 1966). Many other strains of MHV have "now been described (see Table 1). All have been found to cause both hepatitis and encephalitis, although most are either primarily encephalitogenic or hepatitogenic. Intravenous infection of susceptible mice with strain MHV-3 leads to the appearance of infectious virus in spleen, liver, brain, kidney, lung, heart, testicles and numerous other organs (PIAzzA, 1967). The pathology of the hepatic disease by both light and electron microscopy has been described in detail (Bailey et al., 1949; Gledhill and Andrewes, 1951; Nelson, 1952; Miyai et al., 1963; Dick et al., 1956; Ruebner and Bramhall, 1960). Necrosis is focal in nature, and both Kupffer and parenchymal cells appear to be involved. The virus shows in addition a striking ability to destroy lymphoid cells both in the spleen (BigGart and Ruebner, 1970; Hirano and Ruebner, 1965) and the bone marrow (Barinsky and Dementiev, 1968; Hunstein, 1969).

The major problem in MHV control has been the riddance from mouse colonies of subclinical endemic infection (Rowe et al., 1963). This problem has been effectively combatted by means of breeding techniques which have made possible the maintenance of Cesarean-derived, barrier-sustained colonies (Trentin et al., 1966). Such colonies, under proper care and surveillance, can be guaranteed free of all known viruses except those of the mouse leukemia group.

At the present time the importance of MHV lies in its usefulness as a model for various problems in the pathogenesis of hepatitis or encephalitis and in studies of virus-cell interaction. It is a curious characteristic of infection by several strains of MHV that pathogenicity is markedly enhanced by various forms of "stress": infestation with Eperythrozoon coccoides (GLEDHILL, 1962), simultaneous infection with murine leukemia viruses (NELson, 1952; Chany, 1969; Gledhill, 1961), polyoma virus (Sturman and Takemoto, 1972), or K-virus of mice (TISDALE, 1963), and pretreatment of mice with corticosteroids (Datta and Isselbacher, 1969; Vella and Starr, 1965; Manso et al., 1959; Hirano and Ruebner, 1965; Bang and Warwick, 1960; Gallily et al., 1964; LAvelle and Starr, 1969). Liver infection in mice by MHV has been used extensively as a model for human viral hepatitis 
(Piazza, 1969). Strain JHM causes wide-spread destruction of myelin in the central nervous system (BAILEY et al., 1949) and has been recently suggested as a possible model for the human demyelinating encephalitides. There has been considerable interest in variations of the genetic susceptibility to MHV infection in cells obtained from different strains of mice, both in vivo and in vitro (BANG and WARwick, 1960; GalliLy et al., 1967; Shif and BANG, 1970a; KANTOCH and BANG, 1962; SHIF and BANG, 1970b).

A detailed and well-referenced review of MHV research has been published recently, and the reader is referred to it for information about the pathogenesis of murine hepatitis and its value as a model for human disease (PIAZZA, 1969).

\section{Human Coronavirus Strains}

The existence of ether-labile viruses which caused colds in human volunteers but were unrelated to known myxo- or paramyxoviruses was first suspected by TyRrell and Bynoe (1965). These workers were able to passage a virus recovered from the human upper respiratory tract in organ cultures of human embryonic trachea. The virus, named B 814 strain, was subsequently examined by electron microscopy (ALMEIDA and TYRRELL, 1967) and found to resemble the previously described particles obtained from cultures of IBV (BERRY et al., 1964).

HAMre and PRocknow (1966), working independently, recovered five virus strains from medical students with colds which were grown, with some difficulty, in secondary human embryonic kidney monolayers or in human diploid fibroblasts. The prototype virus, strain $229 \mathrm{E}$, was shown to be ether-labile, medium-sized, and RNA-containing, and was later found to resemble IBV and strain B 814 in electron microscopic appearance (AlmeIDA and TYRRELL, 1967).

The organ culture technique was subsequently used to recover 9 further human strains with identical morphology (MCInTosh et al., 1967b; TYRRELL and Bynoe, 1965; Bradburne and Tyrrell, 1971), and still other strains have been recovered in tissue culture (KAPIKIAN et al., 1969; Oshiro et al., 1971; McIntosh, unpublished). All these human coronavirus (HCV) strains, with a single exception, were originally isolated from specimens obtained during upper respiratory disease. Five strains (B 814, LP, EVS, 229E and OC43) have been administered to human volunteers and cause colds which differ in minor respects from the colds produced by rhinoviruses (TYRRELL and Bynoe, 1965; Bradburne et al., 1967). Seroepidemiologic studies of HCV have shown that infection occurs at all ages and is widespread in populations in the United States and the United Kingdom (McIntosh et al., 1970; KAYE and DowdLE, 1969; KAYE et al., 1971). It is a reasonable estimate of their importance that they are responsible for about $15 \%$ of colds in human adults. Of interest has been the consistent finding that HCV strains are primarily epidemic in the winter and early spring (McInTosh et al., 1970; Cavallaro and Monto, 1970). One recent study has implicated HCV in 
exacerbations of symptoms in adults with chronic bronchitis (PHILlips et al., unpublished studies). Efforts to implicate coronaviruses in lower respiratory tract diseases of children have been disappointing (McINTosh et al., 1970) except in young children with asthma (McInTosh et al., 1973) and in infants under 18 months where pneumonia and bronchiolitis during infeetion with these agents may occur (MUFSon et al., 1972).

A comprehensive review of the human coronaviruses has appeared recently (Bradburne and Tyrrell, 1971).

\section{Transmissible Gastroenteritis Virus of Swine}

A distinct disease characterized by a short incubation period (18-24 hours), high infectivity, diarrhea and vomiting, and a high mortality in piglets under 2 weeks of age was first described and attributed to a virus by DOYLE and Hutchings (1946). The disease characteristically occurs in the winter time (FerRis, 1971; Haelterman, 1962) and is most striking when an outbreak occurs in a farrowing herd, since the symptoms tend to be less severe in the adult animal than in the newborn, where the mortality approaches $100 \%$ (CARTwright et al., 1964; Ferris, 1971).

The virus causing transmissible gastroenteritis (TGE) was first grown in primary pig kidney monolayers by LEE (1956). Many strains have been isolated, either in piglets or in cell culture, and the disease appears to be widely distributed in many parts of the world (B̈̈HR, 1969; GoodwIN and JENNINGS, 1958). Although the virus has been recovered from many organs (CARTWRIGHT, 1966; Konishi and Bankowski, 1967; LeE et al., 1954), the highest virus titers are found in the duodenum and jejunum (Hooper and Haelterman, 1966), and clinical disease is confined primarily to the gastrointestinal tract, where the characteristic pathologic lesion of severe blunting of the jejunal and ileal villi is seen (Pensaert et al., 1970a; Penseart et al., 1970b; Thane, 1968). Virus is shed from the gastrointestinal tract for as long as 8 weeks after infection (LEE et al., 1954). TGE has been suggested as a model for both adult (Haelterman and Hooper, 1967) and childhood (Kelly et al., 1972) diarrhea in man.

Because of the observation that epidemics tend to occur following snow falls, when starlings have a habit of congregating around pens, it has been found that virus fed to starlings appears in bird droppings for 32 hours after feeding (PILCHARD, 1965). It is also likely that dogs and foxes can be infected with the virus (HAELTERMAN, 1962).

The most crucial aspect of control involves effective protection of newborn piglets. Since all known strains of TGE virus are serologically identical (CARTwright, 1966; LeE et al., 1954; Bohl, 1967) the problem of antigenic variation, so familiar to workers in the field of IBV, does not occur. However, effective vaccines must take into consideration the observation that immune mothers confer immunity to their offspring through colostrum and milk. Thus, vaccination of mothers must stimulate adequate levels of secretory 
antibody (Djurickovic and Thorsen, 1970; Thorsen and DJurickovic, 1970; Thorsen and DJURICKovic, 1971).

There has recently been some dispute about the nature of the virus responsible for TGE which deserves comment. One group of workers (MCCLURKiN and Norman, 1966) claimed to have detected two agents in material passaged from infected pig intestines into tissue culture: one agent caused a cytopathic effect and the other did not. This dispute arose partly because convalescent pig sera incubated with preparations of TGE virus failed to neutralize the capacity of these preparations to produce disease (LEE et al., 1954; MCCLURKIN and Norman, 1966). This failure was, however, effectively explained by antigen-antibody dissociation in the stomach (WITTE and EASTERDAY, 1967).

Recently, Norman et al. (1968) claimed that they could separate two agents by phenol extraction of a tissue culture-grown virus mixture. A ribonuclease-sensitive pathogenic agent was derived from this extraction, which appeared to produce TGE in susceptible piglets. However, the data presented did not show convincingly that the agent derived from the phenol-extracted material was different from intact TGEV. Indeed, several other workers (CALetTi et al., 1970; WitTE and EAsterday, 1967) have presented evidence that TGEV is a single agent with the characteristics of a coronavirus. The effect of phenol extraction on purified coronavirus preparations deserves further study.

Clinical aspects of TGE are thoroughly reviewed by E. H. BoHL in his chapter of H. W. Dunne's Diseases of Swine, 3rd Edition (BoHL, 1970).

\section{E. Hemagglutinating Encephalomyelitis Virus}

Of the several viruses implicated in encephalomyelitis syndromes of pigs, one appears to be a coronavirus. The exact pathogenic range of this virus, hemagglutinating encephalomyelitis virus $(\mathrm{HEV})$, is not altogether clear. Some strains appear to cause a severe encephalitis in suckling pigs (RoE and Alexander, 1958; Mitchell, 1963). This disease, which is fatal in close to $100 \%$ of piglets up to one week of age, is characterized by squealing, loss of appetite, vomiting, constipation, occasional diarrhea, progressive paralysis (often accompanied by paddling movements of the legs) and death in 3-4 days (Mitchell, 1963). Slightly older piglets may survive, but they remain sickly and grow poorly for several months. Adult animals apparently develop vomiting and anorexia but usually recover. Strains recovered in Great Britain, apparently serologically identical to the encephalitogenic strains, have been shown to cause "vomiting and wasting disease" of piglets under 2 weeks of age, whose primary symptoms are those of gastrointestinal infection rather than encephalomyelitis (CARtwright et al., 1969; Cartwright and Lucas, 1970). Virus was, however, recovered from the brain, and there were histologic signs of encephalitis. Still another strain was isolated incidentally from an asymptomatic pig (MENGELing et al., 1972).

It appears that all strains of $\mathrm{HEV}$ are serologically closed related or identical. Likewise, all strains hemagglutinate and cause a syncytial cytopathic 
effect in primary pig kidney cells. The appearance of typical coronavirus particles by electron microscopy was first demonstrated by PHILLIP et al. (1971) and subsequently confirmed by Mengeling et al. (1972). The virus was also reported to be antigenically related to the virus of TGE (PHILLIP et al., 1971), although the relation appeared not to be a close one.

\section{F. Rat Coronavirus}

In their studies of antibodies to MHV in species other than the mouse, HARTLEy et al. (1964) found that a high proportion of laboratory rats had apparently experienced infection with that or a related virus. A systematic effort to detect such a virus was made by PARKER et al. (1970) who recovered a coronavirus serologically related to MHV from the lungs of asymptomatic rats. The virus, named rat coronavirus (RCV), was pneumotropic, causing a fatal pneumonitis in newborn suckling rats and an asymptomatic pulmonary infection in adults. Apparently infection was widespread, being found in 3 of 5 specific pathogen free colonies, $100 \%$ of conventional colonies and $40 \%$ of individual rats trapped in the wild.

\section{G. Sialodacryoadenitis Virus}

A virus serologically related to RCV has been recently recovered from rats with sialodacryoadenitis (SDA) (BhAtT et al., 1972). The disease was first described in 1961 (InNES and Stanton, 1961) and was studied pathologically by Jonas et al. (1969). These authors found virus-like particles in thin sections of submaxillary salivary glands which, in retrospect, resemble coronaviruses as described by others. BHATt et al. (1972) studied the properties of this virus and discovered its close resemblance to both $\mathrm{MHV}$ and $\mathrm{RCV}$. There is now preliminary evidence for the existence of still other rat coronaviruses (BHATT, personal communication), but these have not been described in detail.

\section{H. Summary}

It thus appears that members of the coronavirus group are widely distributed in nature and show a variety of tissue and species tropisms. Man, chickens, pigs, mice and rats are naturally infected, and disease is caused by virus multiplication and cytopathogenicity in the upper and lower respiratory, tract, the kidneys, the genital tract, the small and large intestines, the brain, the salivary glands and elsewhere. It appears likely that coronaviruses infecting other species will be found. As was mentioned previously, antibody to TGE virus has been found in dogs (Norman et al., 1970), and this could represent either infection with TGE virus or, possibly, evidence of a related canine virus. Moreover, a virus associated with infectious feline peritonitis has been described which has a morphology in thin sections making it a likely candidate for a cat coronavirus (WARD, 1970; WARD et al., 1968).

It is the purpose of the following section to discuss common issues of importance among all the known members of the coronavirus group. It will 
be seen that, although the coronaviruses share many features in common, they differ significantly in certain ways, and the problems facing virologists in their study and control vary widely.

\section{Properties of Coronaviruses}

\section{A. Morphology of the Virion}

\section{Negative staining}

Although the particles in suspensions of IBV were studied by electron microscopy as long ago as 1948 (REAGAN and BRUECKNER, 1952; REAGAN et al., 1948), it was not until the techniques of negative staining were applied that adequate surface morphology was outlined. On the basis of its physical characteristics, IBV had always been classified in the myxovirus group. BERRY et al. (1964) were the first to draw attention to the unique "bulbous appearance of the surface projections" of IBV particles and to the obscure nature of the internal portion of the virus. Both these characteristics were in contrast to influenza virus, which they studied by the same techniques.

Some time later, in attempts to outline the properties of the human coronavirus B 814, Almeida and Tyrrell (1967) described clearly the distinct morphology of that virus strain and strain 229E (HAMre and Procknow, 1966) and their resemblance to IBV. McInTosh et al. (1967b) soon thereafter found that the ether labile viruses they had recovered from man in human embryonic tracheal organ culture had a similar morphology, and in related

Table 2. The size of coronavirus virions as measured by electron microscopy of negatively stained preparations

\begin{tabular}{|c|c|c|c|c|}
\hline $\begin{array}{l}\text { Virus } \\
\text { species }\end{array}$ & $\begin{array}{l}\text { Type or } \\
\text { strain }\end{array}$ & Investigator (s) & $\begin{array}{l}\text { Over-all } \\
\text { diameter } \\
(\mathrm{nm})\end{array}$ & $\begin{array}{l}\text { Length of } \\
\text { projections } \\
(\mathrm{nm})\end{array}$ \\
\hline IBV & $\begin{array}{l}\text { A } 163, \text { H } 17 \\
\text { Conn. \& Mass. }\end{array}$ & BERRY et al., 1964 & $80-120$ & - \\
\hline IBV & 42 & McIntosh et al., $1967 \mathrm{~b}$ & $120-200$ & 20 \\
\hline IBV & $\mathrm{F}$ & Estola and Weckstrom, 1967 & $100-120$ & - \\
\hline IBV & Mass. & NAZERIAN and CUNNINGHAM, 1967 & 110 (av.) & - \\
\hline IBV & $\mathrm{GN}-2$ & Hirai and Shimakura, 1971 & $60-220$ & 20 \\
\hline IBV & Clark-333 & Cowen et al., $1971 \mathrm{~b}$ & $50-100$ & - \\
\hline $\mathrm{HCV}$ & $\mathrm{B} 814,229 \mathrm{E}$ & Almeida and Tyrrell, 1967 & $80-120$ & 20 \\
\hline $\mathrm{HCV}$ & $\mathrm{OC}_{16}, 229 \mathrm{E}$ & McIntosh et al., $1967 \mathrm{~b}$ & $120-200$ & 20 \\
\hline TGE & TO & OKaniwa et al., 1968a & $97-120$ & 12 \\
\hline TGE & TO & TAJiмA, 1970 & $100-150$ & 24 \\
\hline TGE & ? & Phillip et al., 1971 & $133-168$ & 20 \\
\hline $\mathrm{HEV}$ & ? & Phillip et al., 1971 & $140-177$ & 19 \\
\hline $\mathrm{RCV}$ & 8190 & PARKER et al., 1970 & $79-118$ & 17 \\
\hline
\end{tabular}




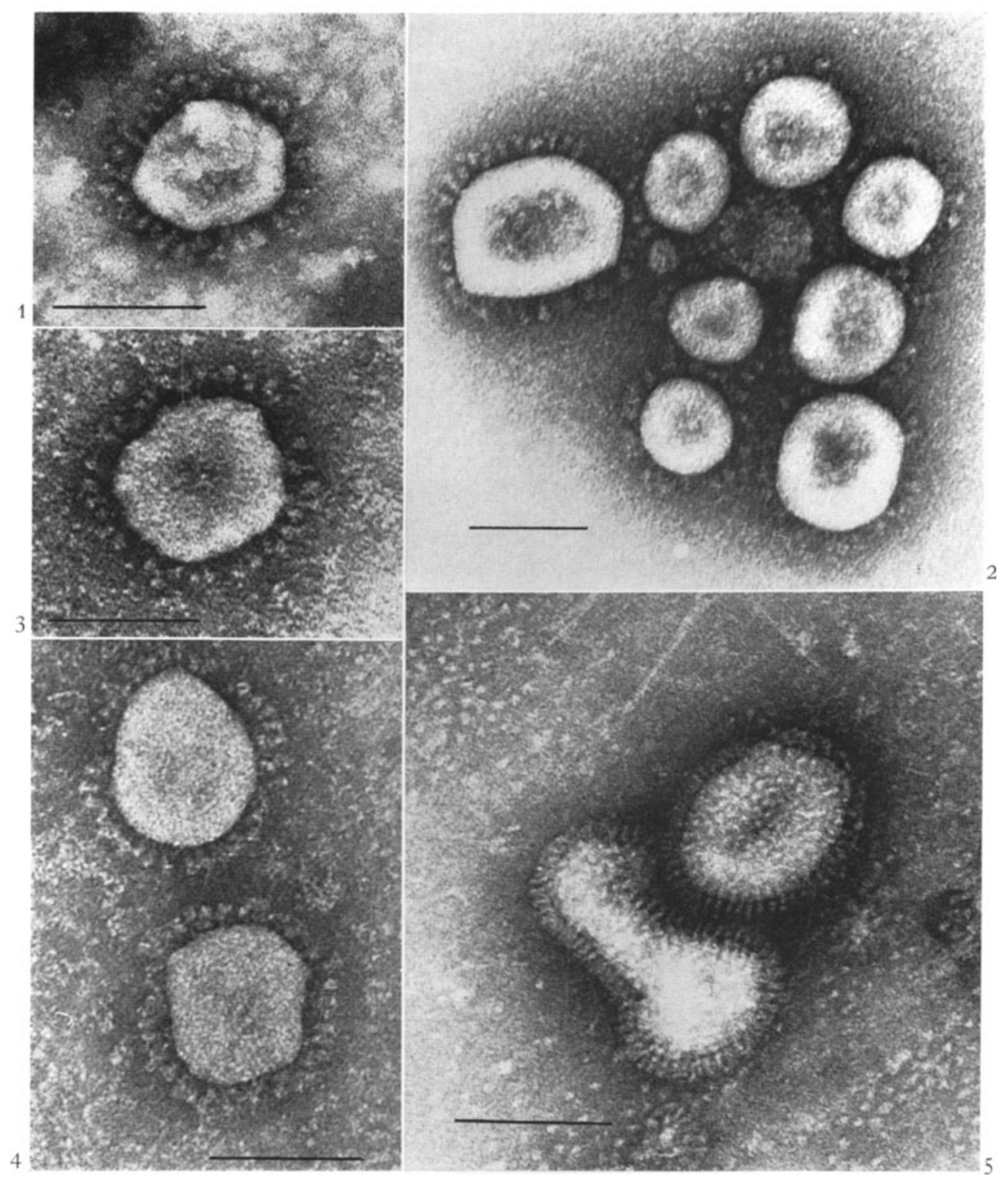

Fig. 1. Human coronavirus, strain 229E, prepared from untreated infected WI-38 cell lysate and stained with $2 \%$ phosphotungstic acid at $\mathrm{pH} 7.0$. Bar represents $100 \mathrm{~nm}$. Figs. 1, 2, 3, and 5 are printed with permission of the Proceedings of the National Academy of Sciences and appeared originally in McIntosh et al., 1967 b

Fig. 2. Human coronavirus. strain OC 16, prepared from infected human embryonic tracheal organ culture fluids, concentrated by ultracentrifugation and stained as in Fig. 1. Bar represents $100 \mathrm{~nm}$.

Fig. 3. Infectious bronchitis virus, strain Beaudette, prepared from infected 10-day embryonated eggs as untreated allantoic fluid. Staining as in Fig. 1. Bar represents $100 \mathrm{~nm}$

Fig. 4. Mouse hepatitis virus, strain A-59, prepared from infected NCTC-1469 cells, untreated. Stained as in Fig. 1. Bar represents $100 \mathrm{~nm}$

Fig. 5. Influenza A 2, negatively stained with phosphotungstic acid, shown for comparison with coronaviruses. Bar represents $100 \mathrm{~nm}$ 


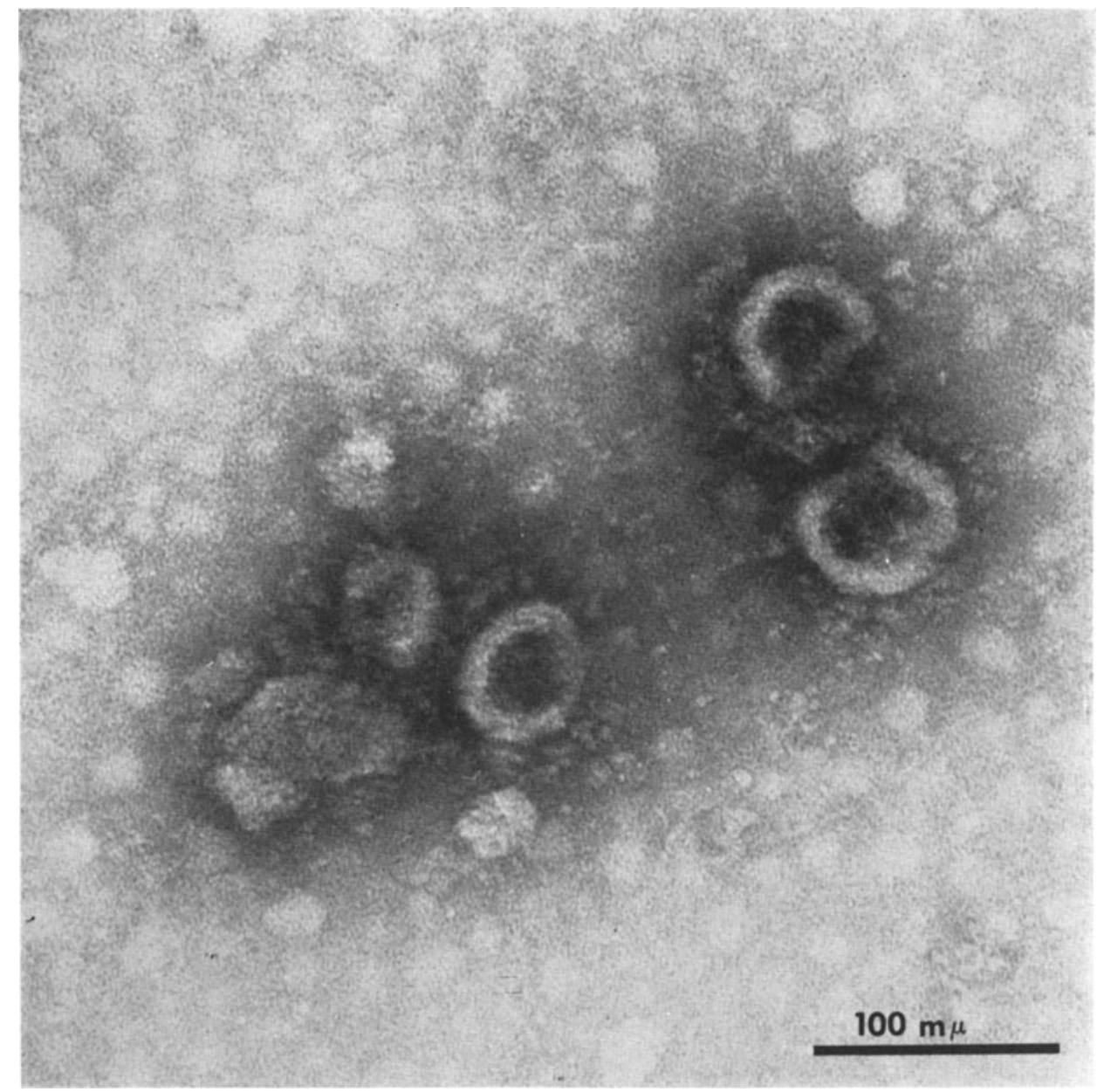

Fig. 6. HCV, strain 229E, treated for 10 minutes at room temperature with tween 80-ether. Projections are distorted or destroyed, and no internal component is visible. Magnification before publication, $\times 288,000$

studies added MHV to this morphologic group (McInTosh et al., 1967a). It was at this point that the name "coronavirus" was coined by an ad hoc international committee (TYrRELl et al., 1968a), the name being descriptive of the "corona" of projections seen in negatively stained preparations. Other members were then, one by one, added to the group on the basis of this characteristic appearance.

Although there is some disagreement between investigators on the exact size range of various coronaviruses, the common properties and the size of the projections of all coronaviruses are clear (see Table 2). Filtration studies (Beach and Schalm, 1936; Beaudette and Hudson, 1937; Estola, 1966; Tevethia and Cunningham, 1968; Cartwright et al., 1965; Sheffy, 1965; McClurkin and Norman, 1966; Hamre and Procknow, 1966; Tyrrell and Bynoe, 1965; Kapikian et al., 1969; Bhatt et al., 1972) tend to confirm the 


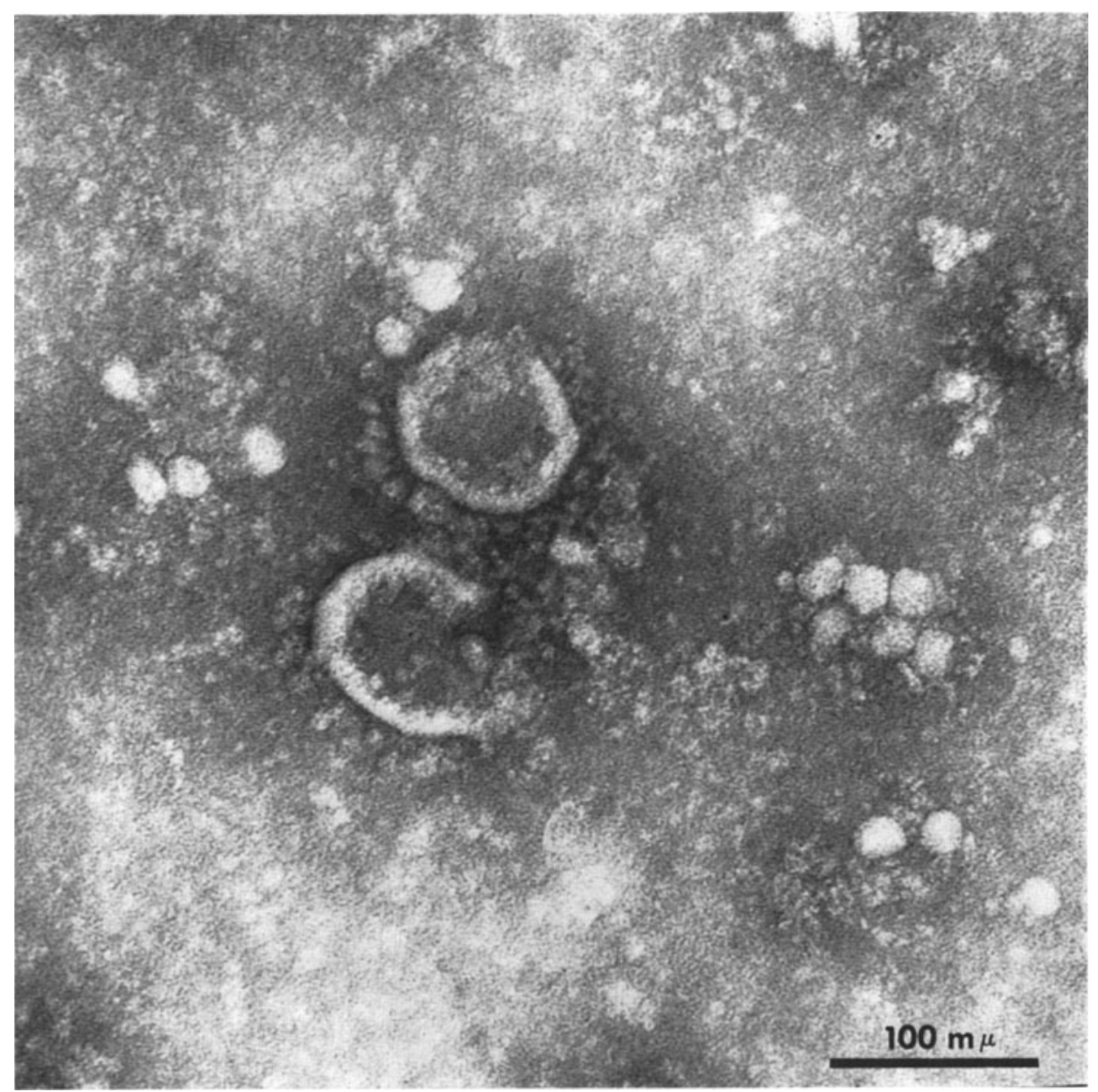

Fig. 7. HCV, strain $229 \mathrm{E}$, treated with $1.0 \%$ sodium dodecylsulfate for 10 minutes at room temperature. The projections are relatively spared, but, again, no internal component is visible. Magnification before publication, $\times 240,000$

measurements obtained on electron microscopy, and will not be outlined in detail. Moderate pleomorphism has been a feature of all coronavirus strains, as have the peculiar club-shaped projections and the characteristic wide spacing of these projections (Fig. 1-5).

Attempts to obtain a consistent picture of the internal structure of coronaviruses by means of negative staining have met with only qualified success. Ether, tween 80-ether, sodium dodecyl sulfate, or desoxycholate treatment of coronavirus suspensions destroys the morphologic integrity of the virus particles and leaves amorphous material which is presumably altered membrane and "internal component" (KAYE et al., 1970; Berry and Cruickshank, 1964) (Fig. 6 and 7). Formalinization of strain $229 \mathrm{E}$ produces particles which seem to extrude a possible internal component. This "loop" (see Fig. 8) appears to remain attached to the external membrane of the virus. 


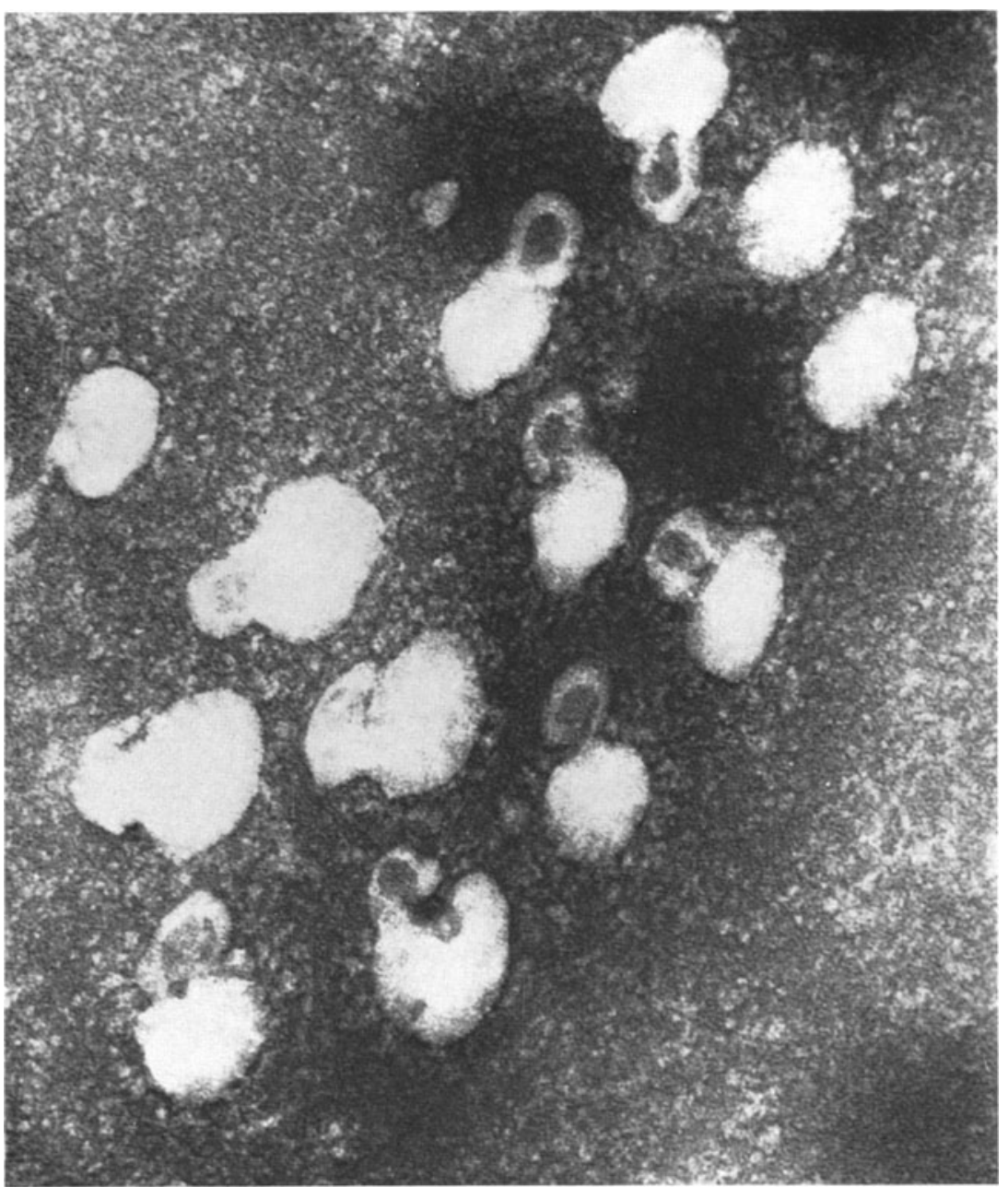

Fig. 8. HCV, strain $229 \mathrm{E}$, treated with $10 \%$ formalin at room temperature for one hour. Many particles appear to be extruding a "loop", which may be related to the "tongues" seen in Figs. 9 and 10. Magnification before publication, $\times 180,000$

Perhaps the most convincing view of coronavirus internal structure has emerged from studies of J. D. Almeida. She has applied a technique which uses antibody and complement to produce small holes in the outer envelope of IBV (BERRY and AlMEIDA, 1968). By this means she introduced phosphotungstic acid inside with little distortion of over-all morphology. Internally projecting "tongues", continuous with the outer membrane of the virus, were observed in virus particles treated this way (Fig. 9 and 10). The relation of these "tongues" to the nucleic acid of the virus is unknown. The "tongues" may be identical to the "loops" seen in formalinized virus preparations. AlmeIDA's observations remain unconfirmed at this time, although they represent a plausible concept of internal structure which is consistent with the findings in fixed ultra-thin sections. 


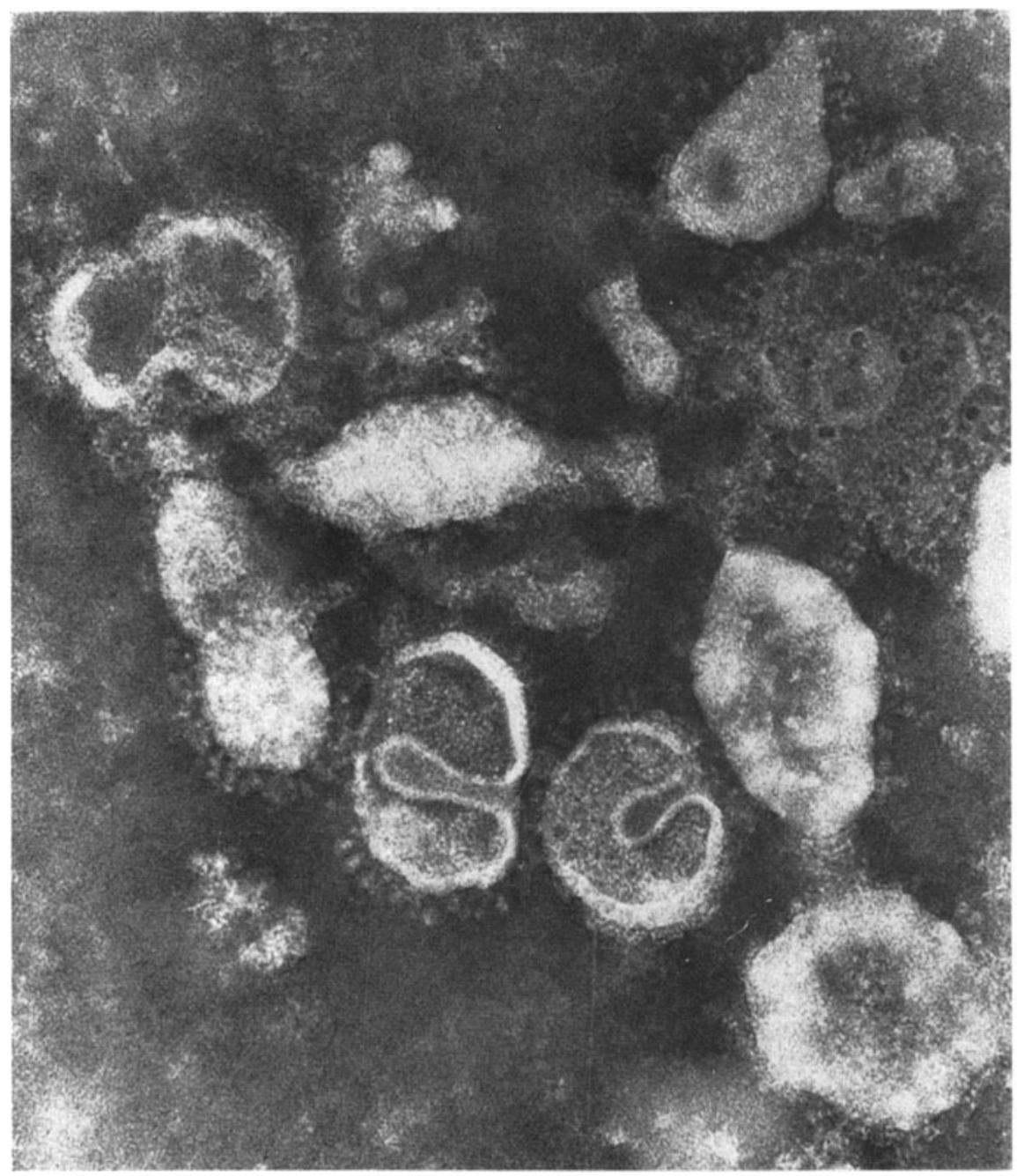

Fig. 9. IBV, incubated before staining with fresh specific (heterologous) rabbit antiserum, unheated. Stained with 3\% phosphotungstic acid. The "holes" are visible in some of the virus envelopes and internally projecting "tongues" are visible. Magnification before publication, $\times 200,000$. Figs. 9 and 10 were kindly supplied by Mrs, J. D. Almeida

\section{Ultra-thin sections}

Just as in the direct examination of virus particles, early investigators described coronaviruses in sections of infected tissue, but no details were seen (Domermuth and Edwards, 1957). Before it was recognized as a coronavirus, the particles of MHV were described in thin sections of mouse liver (STARR et al., 1960). They were thought to be $90 \pm 20 \mathrm{~nm}$ in diameter, round, and clustered in cytoplasmic vesicles. A later study of MHV, strains MHV-2 and MHV-3 (Svoboda et al., 1962), confirmed and extended these findings. Particles thought to be MHV virions were $90 \mathrm{~nm}$ in diameter and contained 


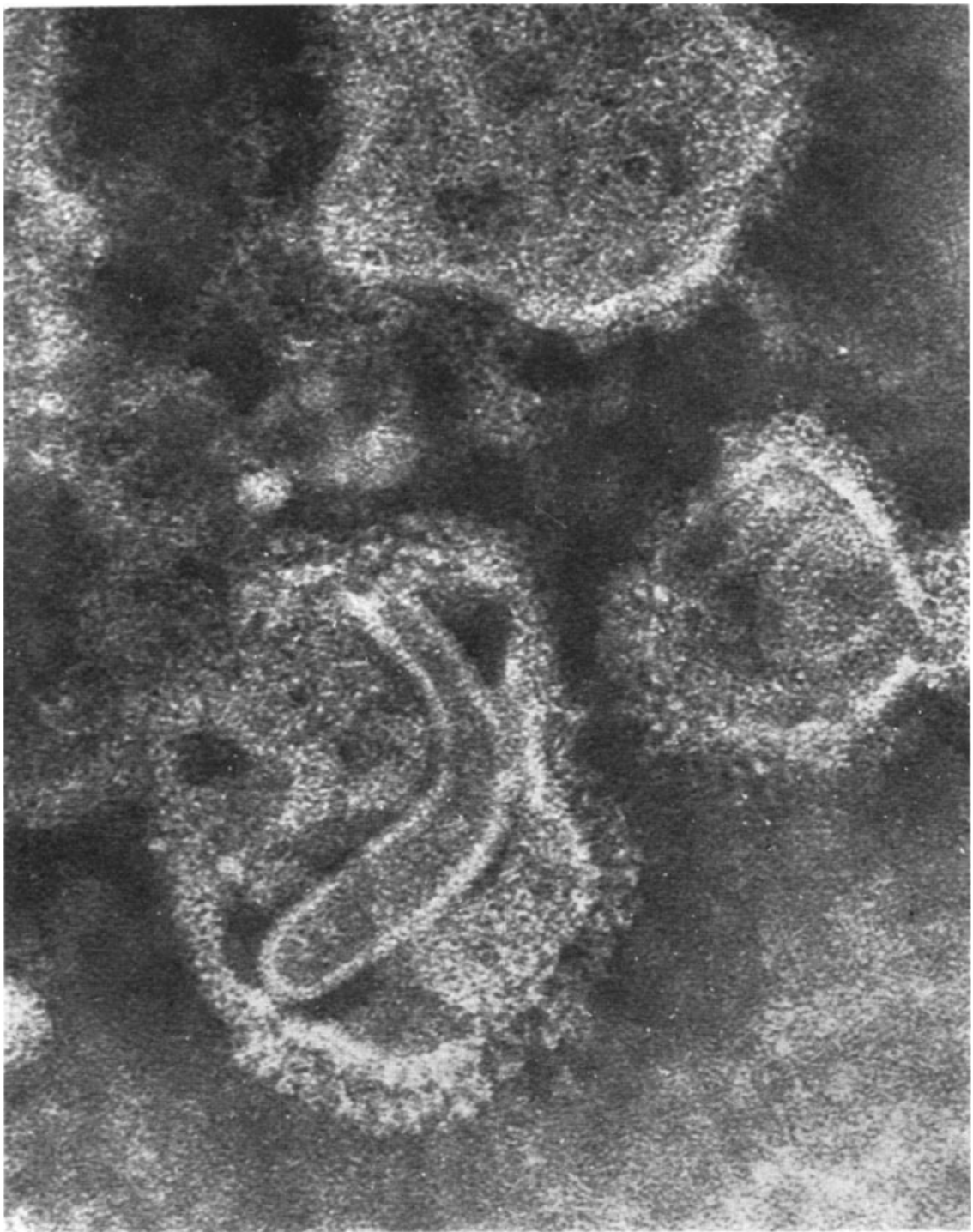

Fig. 10. IBV, incubated before staining with fresh human serum containing antibodies to IBV. Stained as in Fig. 9. A long "tongue" is visible. Magnification before publication, $\times 300,000$

a "nucleoid" separated from the outer membrane by an electron-lucent space. A further study of MHV, strain A-59, described particles in tissue culture cells (David-Ferreira and Manaker, 1965). In this instance, the average diameter of the particles was $75 \mathrm{~nm}$, and an electron-dense inner shell $55 \mathrm{~nm}$ in diameter was observed, which was separated from the outer "double" membrane by an electron-lucent space $8 \mathrm{~nm}$ wide. The studies of BECKER et al. (1967) showed that strain 229E, a human coronavirus grown in WI38 cells, was very similar in morphology to MHV. Fig. 11 shows a detailed section 


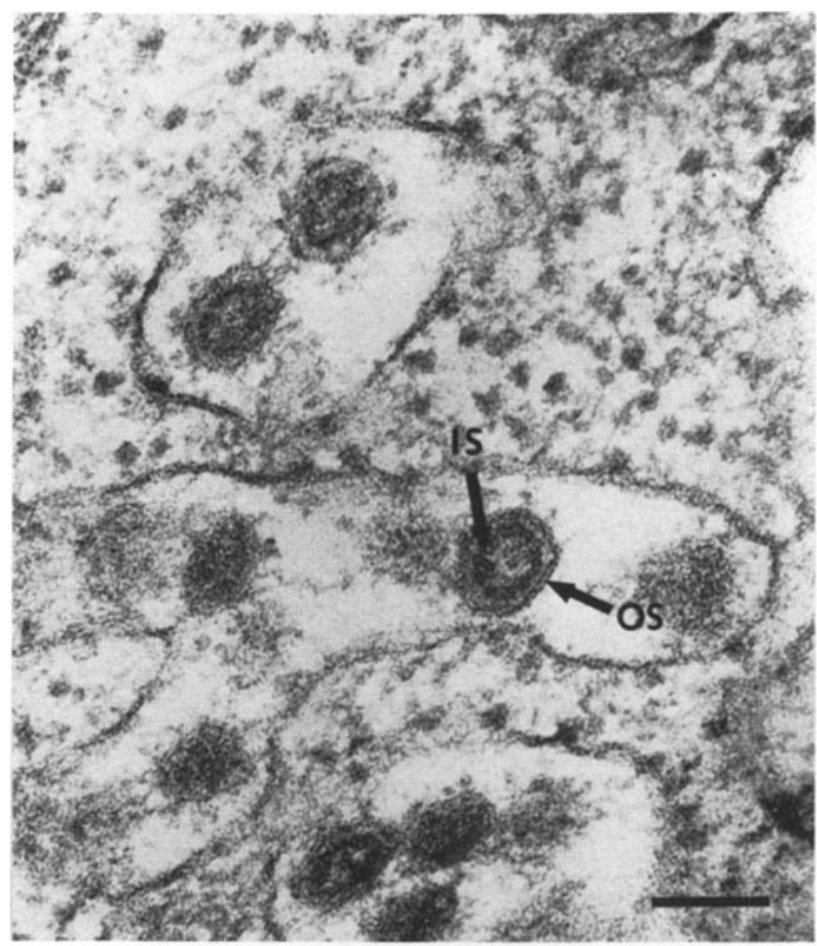

Fig. 11. Cytoplasm of a 229E-infected WI38 cell. Complete virus particles are shown, with the double outer membrane, inner core and space in between. Cells were fixed in $6.5 \%$ glutaraldehyde for 1 hour, post-fixed in $1 \%$ osmium tetroxide and stained with uranyl acetate and lead citrate. IS: inner shell. OS: outer shell. Magnification before publication, $\times 120,000$. Bar represents $100 \mathrm{~nm}$. Figs. 11, 12, and 13 are printed with permission of the American Society for Microbiology and appeared originally in BECKER et al., 1967

of strain $229 \mathrm{E}$ particles, including the inner and outer shells, reproduced from this published paper. In the same study, IBV was described as the same size as $229 \mathrm{E}(67-110 \mathrm{~nm}$, mean $82 \mathrm{~nm})$, but the avian virus showed no evidence of an electron-lucent space between the outer and inner shells (Fig. 12). It is of interest that this feature of IBV, namely the close apposition of the outer and inner shells, was described also by NAzERIAN and CunNingham (1968) and Cowen et al. (1971b). However, the recent micrographs of UpPaL and CHU (1970) show the space present. Thus, it appears that there is no consistent difference in morphology between IBV and the human or murine coronaviruses.

Apostolov et al. (1970) have recently examined thin sections of purified IBV particles. They described an "internal thread-like structure $7-8 \mathrm{~nm}$ in diameter". The morphologic definition of that structure, however, was not absolutely clear from their published micrographs. It may represent the structure described as the "inner shell" by BECKER et al. or as the "core" by others. 


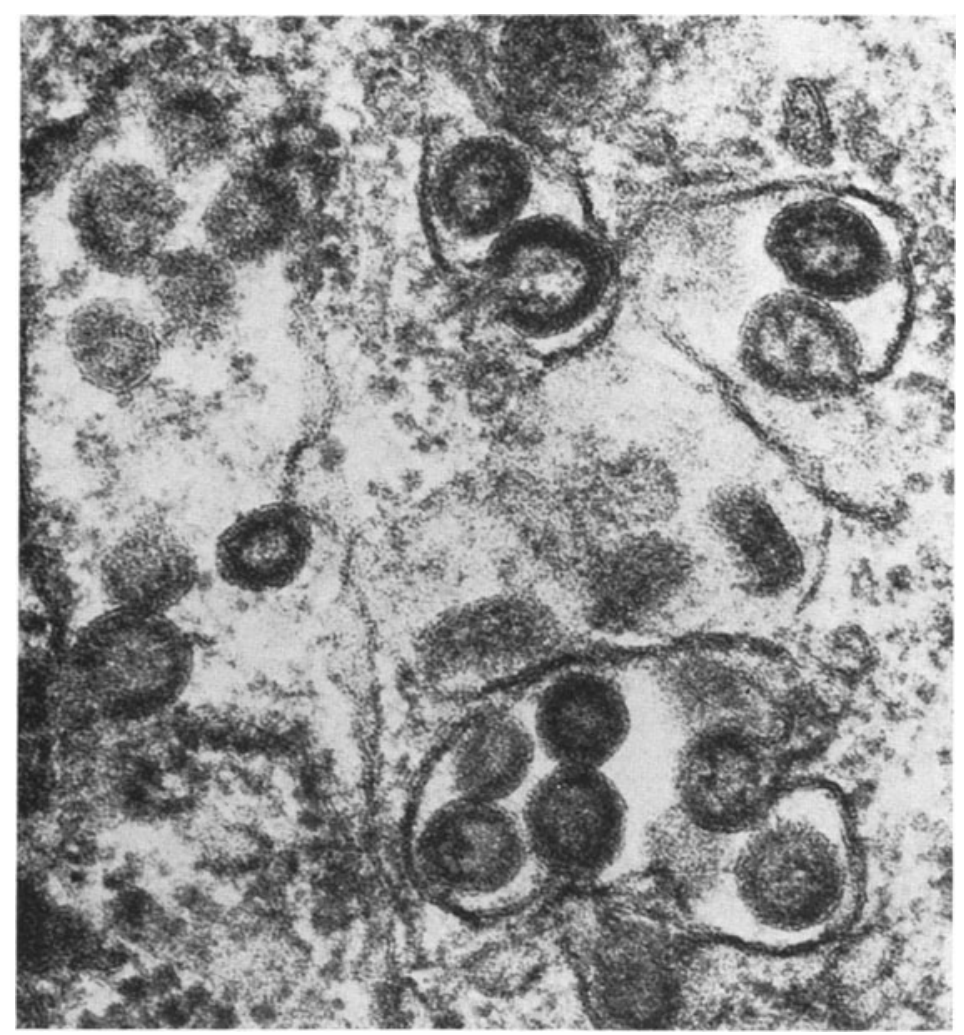

Fig. 12. Chorioallantoic membrane cell infected with IBV, Beaudette strain. Complete virus particles show no space between the core, or inner shell, and outer membrane. Fixation and staining as in Fig. 11. Magnification before publication, $\times 120,000$

Virus particles with a size and morphology similar to those of strain $229 \mathrm{E}$ have been described for TGE virus (BRADFUTE et al., 1970; ChANDler et al., 1969; OKaniwa et al., 1968b; Thake, 1968; Vetterlein and Liebermann, 1970; Witte et al., 1968), HEV (Mengeling et al., 1972), RCV (Parker et al., 1970) and SDA virus (Jonas et al., 1969). Numerous studies of MHV in mouse liver and spleen cells have been published (WATANABE, 1969; Ruebner and Bramhall, 1960; Cuccurullo and Piazza, 1964; Ruebner et al., 1967; BigGaRT and RUEBNER, 1970), and all are in essential agreement with the findings of others. It is of interest that infectious feline peritonitis virus shows a very similar morphology and morphogenesis, although micrographs confirming a coronavirus-like appearance in negatively stained preparations have not been published (WARD, 1970).

\section{B. Physical and Chemical Characteristics of Coronaviruses}

1. Nature of the nucleic acid

In all instances where they have been so studied the growth of coronaviruses has been shown to be insensitive to the action of inhibitors of DNA 
metabolism (Bohl and Kumagai, 1965; Harada et al., 1968; McClurkin and Norman, 1967; Pensaert, 1970; Sheffy, 1965; Witte et al., 1968; Caletti et al., 1968; Greig and Girard, 1969; Estola, 1966; Tevethia and Cunningham, 1968; Mallucci, 1965 ; Hamre and Procknow, 1966; Kapikian et al., 1969; McIntosh et al., 1967b; BRAdBURne, 1969). The inhibitors which have been tested have been principally 5'-iododeoxyuridine and 5'-bromodeoxyuridine, but cytosine arabinoside (PARker et al., 1970), 5'-fluorodeoxyuridine (Estola, 1966; MallucCI, 1965) and aminopterin (AKers and Cunningham, 1968) have also been used. These inhibitors do not affect either the induction of cytopathic effect $(\mathrm{CPE})$ or the production of new viruses. Likewise, actinomycin D $(0.01-1 \mathrm{mg} / \mathrm{ml})$ has no effect on the CPE produced by several coronavirus strains (MCClurkin and Norman, 1967; PARKer et al., 1970; MalluCCI, 1965; McIntosh, unpublished).

Because of these studies, the nature of the coronavirus nucleic acid has been thought to be RNA. Direct extraction and analysis of the nucleic acid from highly purified virions, including determination of single- or doublestrandedness, have not been reported.

\section{Sensitivity to Lipid Solvents}

Both ether and chloroform destroy or markedly reduce the infectivity of coronaviruses. It is likely, in view of their morphology and morphogenesis in thin sections, that the outer shell of the virus consists of cell-derived membrane which contains lipid and is necessary for infectivity.

There have been many attempts to visualize the interior of the virion by examining ether or ether-tween treated virus in the electron microscope. As seen in Fig. 6, one can observe the disintegration of the virion by this method, but there remains little or no organized internal structure (KAYE et al., 1970; BerRY et al., 1964; NAZERIAN and CunninghaM, 1967). Treatment with detergents such as sodium dodecyl sulfate and sodium desoxycholate has a similar destructive effect (Fig. 7), following which little infectivity or organized structure remains (CARTWRIGHT et al., 1965; KAYE et al., 1970; Hierholzer et al., 1972; Berry et al., 1964; Estola, 1966; Tevethia and Cunningham, 1968; Greig and Girard, 1969).

\section{Sensitivity to Physical Agents: Heat and Acid}

The details of the stability of coronaviruses at various temperatures depend so markedly on the exact nature of the experimental conditions, the purity of the virus preparations and the presence of ions and colloids in the medium that a summary of the results of studies in this area seems unwarranted. It is clear that most coronaviruses are inactivated at $56^{\circ} \mathrm{C}$ in $10-15$ minutes, at $37^{\circ} \mathrm{C}$ in several days, and at $4^{\circ} \mathrm{C}$ in several months (Hofstad, 1956; Estola, 1966; Witte and Easterday, 1967; Sheffy, 1965; Harada et al., 1968; von Bülow, 1967; Hironao et al., 1970; Hirai and Shimakura, 1971; Cowen et al., 1971b; Bucknall et al., 1972b; Page and Cunningham, 
K. McIntosh :

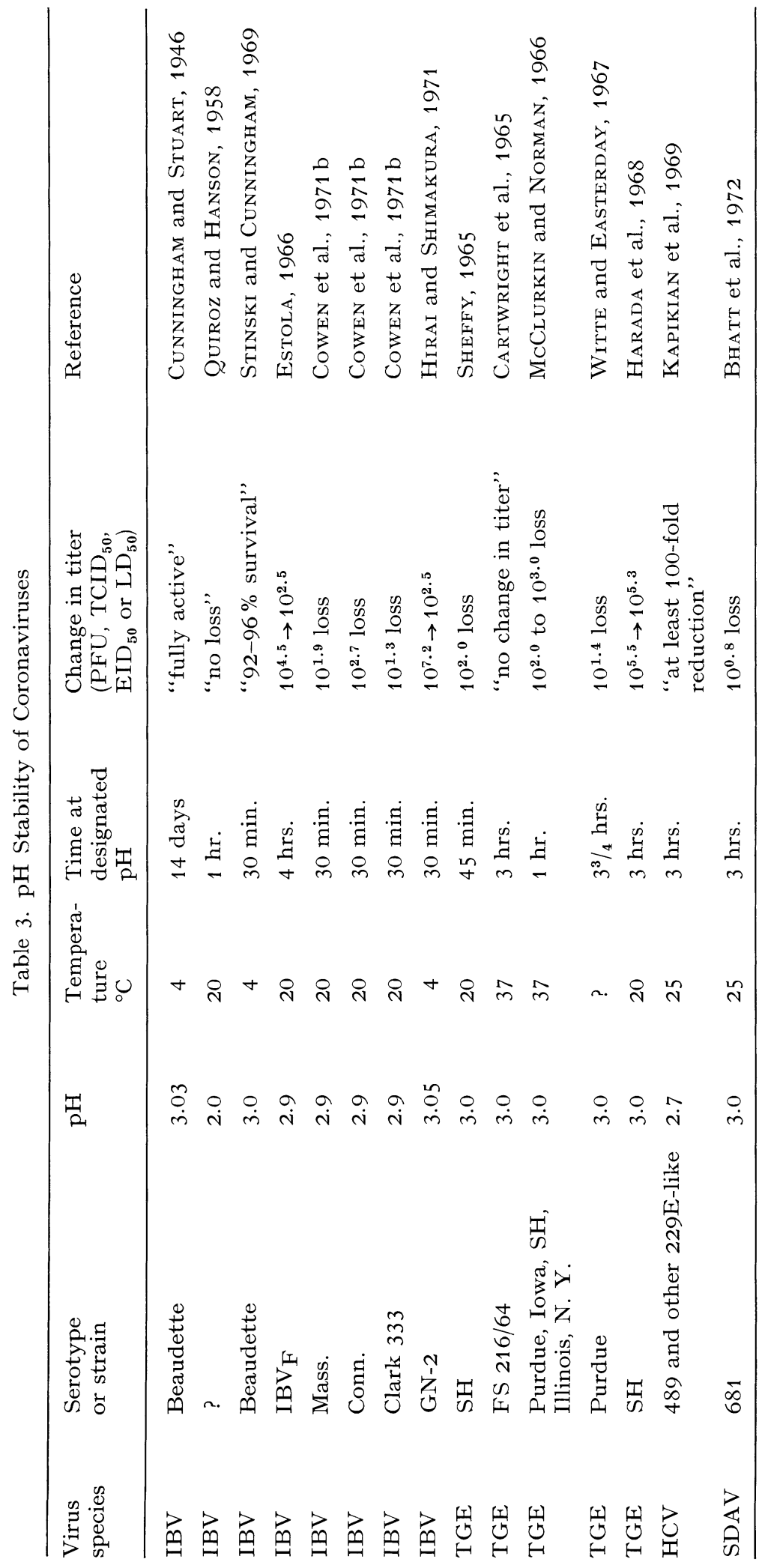


1962). The viruses are generally quite stable through several freeze-thaw cycles and may be kept at temperatures of $-60^{\circ} \mathrm{C}$ or lower for years without loss of infectivity. There may be considerable variation in thermolability between different egg passages of the same strain (von BüLOw, 1967). On the other hand, more detailed studies of two human coronavirus strains demonstrated that differences in susceptibility to heat were almost entirely accounted for by differences in aggregation (BuckNaLl et al., 1972b).

Investigators disagree regarding the stability of various coronaviruses at acid $\mathrm{pH}$. It is not clear whether these disagreements reflect differences in methods or in strains of coronaviruses tested. Some of the published results of stability tests are shown in Table 3. It is clear that a systematic and standardized study of the $\mathrm{pH}$ stability of coronaviruses should be performed.

\section{Chemical Composition of the Virion}

The presence of lipids essential to infectivity has been amply demonstrated by the action of detergents and lipid solvents on coronavirus particles. Similar early attempts to demonstrate essential proteins concentrated on the effect of trypsin on virus infectivity. Although there is some disagreement on the point (Corbo and Cunningham, 1959; Nazerian and Cunningham, 1967), the bulk of evidence indicates that the biological activity of coronaviruses IBV and TGEV is not sensitive to trypsin (Estola, 1966; Steele and Luginbuhl, 1964; von Bülow, 1967; Cowen et al., 1971b; Sheffy, 1965; Cartwright et al., 1965; Harada et al., 1968; Muldoon and Cunningham, 1961) and that, indeed, there is no morphologic effect of this or other proteolytic enzymes on IBV (Berry et al., 1964; Apostolov et al., 1970). On the other hand, purified human coronavirus $\mathrm{OC} 43$ loses its infectivity, its complement fixing activity, and much of its hemagglutinating ability when treated with $1 \%$ trypsin for 2 hours (KAYE et al., 1970).

More recently, coronavirus OC43 has been extensively purified by batch CaHPO4 chromatography, and the solubilized polypeptides have been analyzed by polyacrylamide gel electrophoresis (HIERHOLzER et al., 1972). In these recent studies six or seven separate polypeptides were identified in purified virions with molecular weights varying from 15000 to 191,000 daltons. Four polypeptides contained carbohydrates and one contained lipid. Bromelin treatment (Compans et al., 1970) removed the projections, and purified "bald" particles lacked two of the four glycopeptides, numbers 2 and 6 .

Hierholzer et al. (1972) tested purified OC43 virions for neuraminidase by the sensitive technique of LAVER and Kilbourne (1969) and found none. Earlier, BERRY et al. likewise found no detectable neuraminidase activity in partially purified preparations of IBV (1964). Some neuraminidase activity has been reported associated with the hemagglutinating activity of allantoic fluid harvested from IBV-infected eggs (BIswal et al., 1966). It appears likely, however, that this activity is not part of the infectious IBV particle itself (see below). 


\section{Buoyant Density of the Virion}

There are several reports of the buoyant densities of coronaviruses in gradients of various compositions (Table 4). Infectivity of coronaviruses is preserved both in sucrose and potassium tartrate, but is much reduced in $\mathrm{CsCl}$ (Tevethia and Cunningham, 1968).

Table 4. Buoyant Density of Coronaviruses by Equilibrium Centrifugation

\begin{tabular}{|c|c|c|c|c|}
\hline $\begin{array}{l}\text { Corona- } \\
\text { virus } \\
\text { species }\end{array}$ & Strain & $\begin{array}{l}\text { Gradient } \\
\text { substance }\end{array}$ & $\begin{array}{l}\text { Buoyant } \\
\text { density } \\
(\mathrm{gm} / \mathrm{ml})\end{array}$ & References \\
\hline $\mathrm{HCV}$ & $\begin{array}{l}\mathrm{OC} 43 \\
\mathrm{OC} 43 \\
229 \mathrm{E}\end{array}$ & $\begin{array}{l}\text { Sucrose } \\
\text { K Tartrate } \\
\text { Sucrose }\end{array}$ & $\begin{array}{l}1.19 \\
1.18 \\
1.18\end{array}$ & $\begin{array}{l}\text { KAyE et al., } 1970 \\
\text { HiERHOLzER et al., } 1972 \\
\text { BradBURNe and TyRRELL, } 1971\end{array}$ \\
\hline IBV & $\begin{array}{l}? \\
\text { Beaudette }\end{array}$ & $\begin{array}{l}\text { Sucrose } \\
\mathrm{CsCl}\end{array}$ & $\begin{array}{l}1.19 \\
1.23\end{array}$ & $\begin{array}{l}\text { Cunningham, } 1970 \\
\text { Tevethia and Cunningham, } 1968\end{array}$ \\
\hline TGE & Purdue & Sucrose saline & 1.19 & Witte et al., 1968 \\
\hline
\end{tabular}

HiERHolzer et al. (1972) reported that treatment of the virion of strain OC43 with bromelin decreased the buoyant density in potassium tartrate gradients from 1.18 to $1.15 \mathrm{gm} / \mathrm{ml}$ with concomitant removal of the surface projections.

\section{Coronaviruses in Infected Cells}

\section{A. Growth of Coronaviruses in Cell Monolayers and Laboratory Animals}

The major impediment to progress in research on certain members of the coronavirus group has been the fastidious nature of their growth requirements in the laboratory. This problem is particularly acute in the cultivation of the human strains but also exists to some extent in research on IBV, TGEV, RCV, SDAV and MHV (BARINSKY, 1967).

Table 5 shows a summary of the available information on the growth of coronaviruses in animals and cell monolayers. The table is in certain instances somewhat misleading: at times although virus growth in one or another cell type has been conclusively demonstrated, this growth has been of limited extent and poorly reproducible in different laboratories. This characteristic has rendered this particular cell or tissue unsuitable for general research.

Of particular importance has been the difficulty in cultivating field strains of IBV in any tissue except embryonated eggs. This feature has led to confusion in the areas of serologic typing, the definition of antigenic relationships between strains, and the choice of suitable strains for use in vaccines. Extensive adaptation, first to eggs and then to chick embryo kidney or chicken kidney monolayers, is necessary before sophisticated antigenic comparisons can be made. This adaptation has been performed only for a limited number of field strains. 
Table 5. Growth of coronaviruses in various animals, tissue cultures and organ cultures

\begin{tabular}{lll}
\hline $\begin{array}{l}\text { Corona- } \\
\text { virus }\end{array}$ & $\begin{array}{l}\text { Serotype or } \\
\text { strain }\end{array}$ & Animal or tissue \\
species & & \\
\hline
\end{tabular}

\section{A. Primary Isolation}

IBV all

MHV all

MHV MHV-1

MHV MHV-3

$\mathrm{HCV} \quad \mathrm{B} 814$

$\begin{array}{ll}\text { MHV } & \text { A-59 } \\ \text { MHV } & \text { MHV-2 } \\ \text { MHV } & \text { MHV-B } \\ \text { HCV } & 229 \mathrm{E}\end{array}$

$\mathrm{HCV}$ “OC” strains

TGEV all

TGEV Purdue human embryonic tracheal organ culture

IBV has been isolated primarily only in chickens or in embryonated hens' eggs

all strains of MHV have been isolated in suckling mice

NCTC-1469 (tc a)

$1^{\circ \mathrm{b}}$ mouse kidney (tc)

mouse embryo (tc)

NCTC-1469

$1^{\circ}$ mouse liver (tc)

mouse macrophage (tc)

mouse embryo

NCTC-1469, $1^{\circ}$ mouse spleen (tc)

NCTC-1469

mouse liver macrophage (tc)

$1^{\circ}$ mouse liver

$2^{\circ} \mathrm{c}$ human embryonic kidney (tc), WI-38 (tc)

Human embryonic intestine fibroblast (tc)

$1^{\circ}$ human embryonic kidney (tc), HeLa (tc)

L-132 (tc)

human embryonic tracheal organ culture

human embryonic tracheal organ culture

L-132

all strains of TGEV have been isolated primarily in suckling and weanling pigs

$1^{\circ}$ pig kidney (tc)

$1^{\circ}$ fetal pig kidney (tc),

$1^{\circ}$ fetal pig thyroid (tc)

$1^{\circ}$ canine kidney $(\mathrm{tc})$
Hartley and Rowe, 1963

Starr and Pollard, 1960

Gompels and Niven, 1953

Hartley and Rowe, 1963

Vainio, 1961; Paradisi, 1968

Mallucci, 1965; Vainio and JUDAH, 1962

HAFF, 1962

MANAKer et al., 1961

Hartley and Rowe, 1963

BANG and WARWICK, 1960

Miyazaki et al., 1957

HAMre and Procknow, 1966

KAPIKIAN et al., 1969

Bradburne and Tyrrell, 1969

Bradburne and Tyrrell, 1969; Bradburne, 1969

Bradburne et al., 1967

Tyrrell and Bynoe, 1965

Bradburne and TyrRell, 1969; BRADBURNE, 1969

McIntosh et al., $1967 \mathrm{~b}$

Bohl and Kumagai, 1965;

Witte and EAsterday, 1967

Witte and Easterday, 1967

WeLter, 1965

a tc $=$ tissue culture.

b $1^{\circ}=$ primary.

c $2^{\circ}=$ secondary. 
Table 5 .

\begin{tabular}{|c|c|c|c|}
\hline $\begin{array}{l}\text { Corona- } \\
\text { virus } \\
\text { species }\end{array}$ & $\begin{array}{l}\text { Serotype or } \\
\text { strain }\end{array}$ & Animal or tissue & Reference \\
\hline TGEV & New York II & $1^{\circ}$ pig kidney & $\begin{array}{l}\text { BoHL and Kumagai, 1965; } \\
\text { LEE, } 1956\end{array}$ \\
\hline TGEV & $\mathrm{SH}$ & $1^{\circ}$ pig kidney & $\begin{array}{l}\text { Bohl and Kumagai, 1965; } \\
\text { Harada et al., } 1963\end{array}$ \\
\hline TGEV & FS216/64 & $1^{\circ}$ pig kidney & $\begin{array}{l}\text { CARTWRIGHT et al., 1964; } \\
\text { MCCLURKIN, } 1965\end{array}$ \\
\hline TGEV & Ukiha & $\begin{array}{l}1^{\circ} \text { pig kidney. } 1^{\circ} \text { pig spleen } \\
\text { (tc) }\end{array}$ & Eтo et al., 1962 \\
\hline TGEV & field strains & $2^{\circ}$ pig thyroid $(\mathrm{tc})$ & WitTe, 1971 \\
\hline $\mathrm{HEV}$ & & $\begin{array}{l}\text { most strains of } \mathrm{HEV} \text { have } \\
\text { been isolated primarily in } \\
\text { suckling pigs }\end{array}$ & \\
\hline $\mathrm{HEV}$ & HEV-1 & $1^{\circ}$ pig kidney & GREIG and GIRARD, 1963 \\
\hline $\mathrm{HEV}$ & $67 \mathrm{~N}$ & $1^{\circ}$ fetal pig kidney & MENGELING et al., 1972 \\
\hline $\mathrm{RCV}$ & 8190 & $\begin{array}{l}\text { suckling rats. } 1^{\circ} \text { rat kidney } \\
\text { (tc) }\end{array}$ & PARker et al., 1970 \\
\hline SDAV & 681 & suckling rats. suckling mice & Bнatт et al., 1972 \\
\hline
\end{tabular}

\section{B. Adaptation studies}

IBV Beaudette suckling mice

$1^{\circ}$ chick embryo fibroblast

(tc)

$1^{\circ}$ chick embryo kidney (tc)
Estola, 1967; Simpson and GROUPÉ, 1959

LUKERT, 1966; FAHEY and Crawley, 1956

LUKert, 1966; ChURCHILl, 1965; CHOMIAK, 1958; CUNNINGHAM and SPRING, 1965; Mohanty and Chang, 1963

$1^{\circ}$ Rhesus monkey kidney (tc), FAHEY and CRAwLEY, 1956 $1^{\circ}$ chick embryo heart (tc)

$1^{\circ}$ chick embryo lung (tc)

$1^{\circ}$ chick embryo liver (tc)

LUKERT, 1966

LUKERT, 1966; FAHEY and

Crawley, 1956

Estola, 1967

ColWell and LuKert, 1969;

JoHnson et al., 1969

Estola, 1966 mice, $1^{\circ}$ chick embryo kidney, $1^{\circ}$ chick embryo fibroblast

IBV 16 Japanese

field strains $\quad 1^{\circ}$ chicken kidney (tc)

MHV A $59 \quad$ Syrian hamsters, WI-38

MHV MHV (Balb C) L cells (tc)

$\mathrm{HCV} \quad 229 \mathrm{E}$

HeLa, $1^{\circ}$ human embryonic lung (tc)
Kawamura et al., 1961

McIntosh et al., 1969

MosLey, 1961

Bradburne and TyRrell, 1969 
Table 5 .

\begin{tabular}{|c|c|c|c|}
\hline $\begin{array}{l}\text { Corona- } \\
\text { virus } \\
\text { species }\end{array}$ & $\begin{array}{l}\text { Serotype or } \\
\text { strain }\end{array}$ & Animal or tissue & Reference \\
\hline \multirow[t]{2}{*}{$\mathrm{HCV}$} & OC $38-43$ & $\begin{array}{l}\text { suckling mice } \\
\text { suckling hamsters } \\
1^{\circ} \text { Rhesus monkey kidney, } \\
1^{\circ} \text { vervet monkey kidney (tc), } \\
\text { BS-C-1 (tc) }\end{array}$ & $\begin{array}{l}\text { McIntosh et al., } 1967 \text { a } \\
\text { McIntosh et al., } 1969 \\
\text { BRÚčKovÁ et al., } 1970\end{array}$ \\
\hline & & WI-38 & KAPIKIAN et al., 1972 \\
\hline TGEV & Ukiha & embryonated hens' eggs & Eто et al., 1962 \\
\hline TGEV & $?$ & dogs, foxes & HaELterman, 1962 \\
\hline TGEV & FS 216/64 & $\begin{array}{l}\text { pig intestinal and nasal } \\
\text { organ culture }\end{array}$ & RUBinsteIn, 1970 \\
\hline SDAV & 681 & $1^{\circ}$ rat kidney & BнAтt et al., 1972 \\
\hline
\end{tabular}

Several strains of IBV have been successfully grown in chicken tracheal organ cultures (Colwell and Lukert, 1969; Johnson et al., 1969). The viruses produce a rapid ciliary immobilizing effect without the necessity for adaptation by subpassage. This system has not yet been employed either in the primary isolation of field strains or in serologic studies.

It is also clear that some strains of MHV have not shown the fastidiousness in tissue culture of the other coronaviruses. The cell line NCTC-1469 has been particularly useful for the primary isolation and propagation of many MHV strains, both those derived from standard MHV strains and field strains. This cell line is, however, not suitable for the growth of large quantities of MHV for chemical or physical study since it is heavily contaminated with a murine leukemia virus (DAvid-FerReIra and MANaKer, 1965). This adventitious virus is of a size and density very close to that of coronaviruses and would be difficult to remove by centrifugation methods.

Of great importance has been the difficulty of growing many HCV strains in laboratory animals or in cell monolayers, and the requirement for human embryonic tracheal organ cultures for primary isolation of most strains. These features of the human coronaviruses doubtless contributed to their not being recognized until very recently. Indeed, if the factors responsible for the extreme fastidiousness of naturally occurring human strains could be discovered and somehow corrected, it seems highly likely that many new and previously unrecognized strains would be found.

Isolation of TGEV directly from animals in primary pig kidney monolayers has been the most frequent mode of cultivation. Recently, however (WITTE, 1971), secondary pig thyroid cells have been preferred for the recovery of field strains.

The cytopathic effect ( $\mathrm{CPE}$ ) produced by coronaviruses has been variable. Many of the viruses produce syncytia, including IBV-42 (Akers and CunNing- 
ham, 1968; Mohanty and Chang, 1963), HCV strains OC38 and OC43 (BRÜČKovÁ et al., 1970), TGEV (CARTWRight et al., 1965), HEV (MENGELING et al., 1972; Greig and Girard, 1963), MHV (Paradisi, 1968; Mallucci, 1965; Hartley and Rowe, 1963; Laufs, 1967), RCV (Parker et al., 1970) and SDAV (BHATt et al., 1972). However, not all coronaviruses which do produce CPE form giant cells, so that one cannot assign this capacity as a general feature to the coronavirus group. The CPE produced by the non-syncytium-forming viruses, and in some instances seen in addition to syncytium formation, is of a nonspecific degenerative quality.

The cell monolayer, particularly in early tissue culture passages, merely appears "dirty": scattered cells fall off the glass one by one so that the monolayer is frequently repaired as fast as the infected cells degenerate. This may be an explanation for the observation that some coronaviruses produce a $\mathrm{CPE}$ which is more easily recognized when cells are held under agar (BOHL and KumaGaI, 1965).

\section{B. Intracellular Development of Coronaviruses}

\section{Fluorescent Antibody Studies}

There is little doubt that all known coronavirus species develop exclusively in the cytoplasm of infected cells. With the exception of a single report (MoHANTY et al., 1964a), all fluorescent antibody studies of the intracellular development of coronaviruses have shown only cytoplasmic fluorescence (HAMrE et al., 1967; McIntosh, et al., 1969; Konishi and Bankowski, 1967; McClurkin and Norman, 1966; Pensaert, 1970; Stepanek et al., 1971; Berry, 1967; Bito et al., 1971; Colwell and Lukert, 1969; Lukert, 1966; von Bülow and Schneider, 1969; Mallucci, 1965; Mengeling et al., 1972; LUCAS and NAPTHINE, 1971). It appears likely that in the one dissenting report the seed virus used (Beaudette strain of IBV) was contaminated with another virus, possibly an adenovirus, as was reported for certain IBV pools by BERRY and Stokes (1968). There does not appear to be any characteristic fine morphology of the cytoplasmic fluorescence. Certain studies describe it as beginning in the perinuclear region and spreading to involve the entire cytoplasm (Pensaert, 1970). In cells infected at a multiplicity of about 1 , the earliest fluorescence was seen 4 hours after infection (VON BüLOW and ScHNEIDER, 1969).

\section{Electron Microscopic Studies}

Although many investigations of the matter have been conducted (Jonas et al., 1969; Mengeling et al., 1972; Svoboda et al., 1962; Watanabe, 1969; Parker et al., 1970; David-Ferreira and Manaker, 1965; Miyai et al., 1963; Starr et al., 1960; Okaniwa et al., 1968b; Witte et al., 1968; BradfUte et al., 1970; Thake, 1968; Vetterlein and Liebermann, 1970; Becker et al., 1967; Hamre et al., 1967; Oshiro et al., 1971 ; Bucknall et al., 1972a; Nazerian and Cunningham, 1968; Cowen et al., 1971 b; Uppal and Chu, 
1970; RUEBNER et al., 1967) the details of events during morphogenesis of the coronaviruses are not at present finally established. There is agreement in published studies of all members of the group that particles collect during virus development in small and large cytoplasmic vesicles. Likewise there is agreement that virus particles are not observed in the nucleus, and that scattered particles are seen between layers of endoplasmic reticulum (ER) and often in the Golgi apparatus. Some investigators, but not all, have observed budding of virus particles from membranes either of ER or of cytoplasmic vesicles (Hamre et al., 1967; Oshiro et al., 1971; Nazerian and Cunningham, 1968; Bradfute et al., 1970; Vetterlein and Liebermann, 1970; Becker et al., 1967; David-Ferreira and Manaker, 1965; Ruebner et al., 1967; WatanABE, 1969). There appears to be a conspicuous absence of budding from the plasma membranes. In some studies reticular (DAvid-FERREIRA and Manaker, 1965; Seamer, 1965) or tubular (Ruebner et al., 1967; Seamer, 1965; David-Ferreira and Manaker, 1965; Becker et al., 1967; Oshiro et al., 1971; HAMrE et al., 1967) structures have been seen within the cytoplasm of cells in a stage of active virus formation, but the relation of these structures to development of virus particles is not clear.

Budding into small cytoplasmic vesicles has been observed in studies of all the coronavirus groups. The possible events in the budding process were placed in a hypothetical scheme by BECKer et al. (1967). It was postulated that the earliest event in the development of both IBV (strains 41 and 42) and $\mathrm{HCV}$ (strain 229E) was the formation of "crescents": areas of membrane which bulged toward the lumen of the vesicle and onto which a layer of dense material was apposed. These events are shown in Fig. 13 for HCV, strain 229E, in WI 38 cells. The crescents appeared to bulge into the lumen, developing more and more of the dense underlying layer, which ultimately formed a complete inner shell, the nucleoid, about $50 \mathrm{~nm}$ in diameter. The budding process was completed when the outer membrane was pinched off and the virus particle floated free in the vesicular lumen. These "crescents" were observed by the same authors in their study of IBV in the chorioallantoic membrane and by another group of investigators in the morphogenesis of TGEV (VETTERLEIN and LiebermanN, 1970).

If budding really is the major or only mode of virus morphogenesis, it must occur rapidly, since it is seldom observed, despite the presence of large numbers of virus particles in the cytoplasm of infected cells. Alternative modes of development have been suggested (Uppal and Chu, 1970; SeAmer, 1965), but the details of such mechanisms are still vague, even on the morphologic level. Moreover, postulated hypotheses must somehow account for the probable presence in coronavirus particles of host cell antigenic material within the outer envelope (BERry and Almeida, 1968; Hierholzer et al., 1972).

Studies of the morphogenesis of MHV in the livers of infected mice have been in essential agreement with these observations. Certain specific details have been, however, considered to be different. One group of investigators (RUEBNER et al., 1967) felt that entire "nucleoids" (or "inner shells") were 


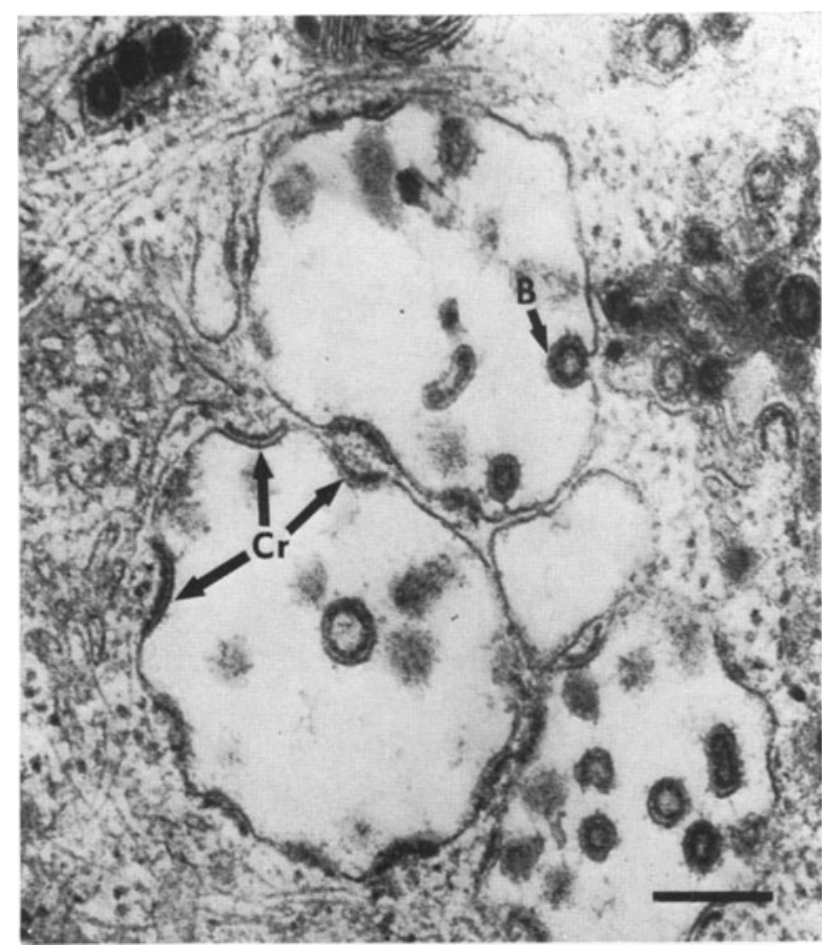

Fig. 13. Cytoplasm of a 229E-infected WI38 cell. Crescents surrounding a large cytoplasmic vacuole, and various stages of budding are seen. $\mathrm{Cr}$ : crescents. B: budding particle. Magnification before publication, $\times 60,000$. Bar represents $200 \mathrm{~nm}$

formed in the cytoplasm in close proximity to cytoplasmic vesicles. These nucleoids then approached the membrane of a vesicle and were considered to bud into it, taking their outer coat from the vesicular membrane. Another group pointed to an increase in the number of free ribosome-like particles within the cytoplasm and felt that these particles might represent differentiating viral internal components (SEAmER, 1965).

The morphogenesis of different coronavirus species in a single host cell type has not been systematically examined, so that comparative statements cannot be made. It appears likely, however, that different coronaviruses have rather similar modes of intracellular development.

\section{Single-cycle Growth Curves}

Some insight into the intracellular development of coronaviruses can be gained from observations of single cycle growth curves. Unfortunately, although many experiments have been described, the multiplicity of infection (MOI) in most studies has been either very low (CARTwRIGHT et al., 1965; Stepanek et al., 1971; Harada et al., 1968; Hirai and Shimakura, 1971) or undefined (McClurkin and Norman, 1966; Sheffy, 1965; Witte and Easter- 
DAY, 1967; von Bülow, 1966; Estola, 1966; Akers and Cunningham, 1968; Kawamura et al., 1961; BradbuRne and TyRrell, 1971). One report (WitTe et al., 1968) described the events following the infection of fetal pig thyroid cell monolayers with the Purdue strain of TGEV, highly tissue culture adapted and at a MOI of about 70. In this study new virus appeared at 4 hours after infection, and the peak of cell-associated infectivity was at 22 hours. These observations agree more or less with those in other well documented reports where other members of the coronavirus group have been studied. At somewhat lower multiplicities and, in certain instances, at undefined multiplicities, new virus appears 4-6 hours after infection and peak titers are reached 12-36 hours after infection (Pensaert, 1970; Lukert, 1965; Hamre et al., 1967; BradBURNe and TYRrell, 1971; BeCKer et al., 1967; Estola, 1966; AKERS and Cunningham, 1968; McCluRkin and Norman, 1966; Mallucci, 1965). In general, cell-associated virus titers rise faster than released virus titers (AKERS and Cunningham, 1968; Lukert, 1965; Harada et al., 1968; Stepanek et al., 1971; HAMre et al., 1967). Further details, such as the sequential development of various viral antigens and the bio-molecular events during infection, are not available.

\section{Immunologic Studies}

\section{A. Virus-Specific Antigens from Coronavirus Infected Cells}

Precipitating antigens from coronavirus infected cells have been recognized for some time. In 1959 a single antigen in allantoic fluid from IBV-infected eggs was precipitated in agar containing immune chicken serum and $8 \% \mathrm{NaCl}$ (WoERNLE, 1959). Hypertonic agar has been used since then in systems containing chicken serum. BERRY and STOKES (1968) found a single common band of precipitation from $10 \mathrm{IBV}$ isolates, using the Ouchterlony technique. TeVethia and Cunningham (1968) studied the precipitating antigens from IBV-42 infected eggs and found three soluble antigens. All three were present in crude concentrated allantoic fluid and in sonicates of infected chorioallantoic membrane (CAM). Antigen 1 diffused most rapidly, passed through a filter of $10 \mathrm{~nm}$ pore size, was trypsin sensitive but not ribonuclease sensitive, and had a buoyant density of 1.14 in $\mathrm{CsCl}$. Antigen 2 diffused at a moderate rate, passed through $50 \mathrm{~nm}$ pores but not those of $10 \mathrm{~nm}$, was ribonuclease and trypsin sensitive, retained its antigenicity at $100^{\circ} \mathrm{C}$ for 60 minutes and had a density of 1.18 in $\mathrm{CsCl}$. Antigen 3 appeared to be larger and was in low concentrations. These workers found that all three antigens could be released from partially purified virus which had been treated with ether for 2 hours.

CHUBB et al. (1971), using different strains of IBV, were also able to identify 3 soluble antigens released from ether disrupted virus particles. However, they found only a single antigen in crude concentrated allantoic fluid and none in sonicated CAM. HironaO et al. (1970) found only a single precipitin band, which was present both in crude allantoic fluid and in homogenized infected CAM. The antigen was trypsin, but not ribonuclease, sensitive and probably, 
therefore, represented antigen 1 of Tevethia and Cunningham. Bradburne (1969) reported 2 antigens to be present in IBV-infected mouse brain.

Similarly detailed studies of TGEV have not been performed. However, PhIllip et al. (1971) reported that a single soluble antigen was present in lysates from both TGEV and HEV infected cells, and that these antigens were identical by the Ouchterlony technique.

Likewise, there is only a single study of precipitating antigens in suspensions of MHV. BRADBURNe (1970) described 2 precipitin arcs when MHV 3 was reacted with homologous hyperimmune serum.

Several investigators have described multiple antigens in crude or purified preparations of human coronaviruses. BRADBURNE (1970) identified two precipitin arcs when strain $229 \mathrm{E}$ was reacted with human postinfection sera. These findings have been confirmed by BRU゚ČKové and McINTOSH (unpublished). Suckling mouse brain grown OC43 contains at least three (HIERHOLZER, 1972; BRŮČKOVÁ and MCINTOSH, unpublished) and perhaps four (BRADBURNE, 1970) separate precipitating antigens. HIERHOLZER (1972) obtained suggestive evidence that one of these antigens was a host cell antigen, since heterologous serum prepared against highly purified OC43 reacted with normal suckling mouse brain suspensions, and heterologous anti-mouse brain serum reacted with purified virus. This indirect evidence is corroborated by the electron micrographs of BERRY and ALMEIDA, which show "holes" in the envelope of IBV created by heterologous anti-IBV serum plus complement. These "holes" may represent material in the membrane which is antigenically host specific since they were not seen when a homologous virus-antibody system was used (BERRY and AlmeIDA, 1968).

Because of the failure in some studies to find multiple "soluble" antigens in untreated coronavirus preparations (KAYE et al., 1970; ChUBB and Cumming, 1971; Berry and Stokes, 1968; Hironao et al., 1970) it appears likely that such antigens are not produced in large quantities, as they are, for example, in adenovirus infected cells. Indeed, those "soluble" antigens which are found in untreated cell culture or allantoic fluids may represent components of spontaneously disrupted whole virion particles.

\section{B. Hemagglutination}

Only two of the coronavirus species agglutinate erythrocytes spontaneously. These are human strains OC38 and OC43 (KAYE and DowdLE, 1969), which are serologically identical and probably represent two strains of the same virus serotype, and HEV (Phillip et al., 1971; MENGeling et al., 1972; GREIG and GIRARD, 1963). Strains OC38 and OC43 were shown to agglutinate human type 0 and vervet monkey erythrocytes at $4^{\circ} \mathrm{C}$ but not at room temperature or $37^{\circ} \mathrm{C}$, and chicken, rat and mouse cells at any of the three temperatures. The highest titers were achieved with rat and mouse cells. Rhesus monkey and guinea pig cells failed to agglutinate. HEV (strain 67N) was found to hemagglutinate rat, chicken, turkey, mouse and hamster erythrocytes at $22^{\circ} \mathrm{C}$. 
Guinea pig, calf, sheep, pig, goose, horse, rabbit and human type 0 red cells failed to agglutinate under the conditions examined.

Ether destroyed the hemagglutinating activity of both viruses. Trypsin was found to destroy that of the HCV strains. Evidence was obtained by KAYE et al. (1970) that the hemagglutinin of strain OC43 is closely associated with, and probably an integral part of, the infectious virion. Moreover, these workers were unable to free hemagglutinating activity from the virion by various physical and chemical procedures. HIERHOLzER et al. (1972) found that bromelin treatment, which removed the clubshaped projections, removed all hemagglutinating activity as well. Moreover, complement fixing activity and infectivity were destroyed at the same time. These experiments suggest strongly that the projections of the OC43 virion attach to red cells. It is possible that these projections must be part of the intact virus particle to cause hemagglutination.

Both OC38-43 and HEV have been found to cause hemadsorption (PHILLIP et al., 1971; Mengeling et al., 1972; Greig and Girard, 1963; Kapikian et al., 1972). This finding, which was unexpected in view of the absence of budding from the cell surface, was explored further by Bucknall et al. (1972a) who found, as others had (HAMre et al., 1967; Oshiro et al., 1971), that human coronavirus particles tended to adhere to the surface of the infected cell monolayer. Added erythrocytes, in turn, adhered to the virus particles. These authors preferred to call the phenomenon "pseudo-hemadsorption". It is likely, although unproven, that the mechanism of HEV hemadsorption is similar.

Immune serum has been found to inhibit the hemagglutinating and hemadsorbing activity of both OC38-43 and HEV (KAPIKIAN et al., 1972; KAYE and DOWDLE, 1969; GIRARD et al., 1964). In serologic surveys, rises in hemagglutination inhibiting antibody to $\mathrm{OC} 43$ tend to parallel rises in complement fixing antibody, further demonstrating the antigenic specificity of the reaction.

Hemagglutination is also observed in trypsin-treated crude allantoic fluid from IBV-infected eggs (CoRBo and Cunningham, 1959). Further studies have demonstrated that the hemagglutinating activity may be detected in untreated allantoic fluid from infected eggs if it is separated from nonspecific inhibitors by column chromatography (BISWAL et al., 1966). This hemagglutination, however, is not associated with intact infectious virus (BISwAL et al., 1966) and is not specifically inhibited by antiviral antiserum (CoRBo and CunNingham, 1959). IBV hemagglutination is therefore not useful as a serologic tool, and, indeed, may not be a specific viral or virus-coded substance.

\section{Complement Fixation}

Various strains of human, mouse, rat and avian coronaviruses have been shown to fix complement in the presence of convalescent or hyperimmune serum. There are no published reports of complement fixation (CF) by porcine viruses. 
The complement fixing antigen of IBV (Beaudette strain) has been studied using guinea pig serum prepared against chicken kidney grown antigen (STEELE and Luginbuhl, 1964). Because concentrated, partially purified virus preparations were used, it appears likely that the antigen measured was attached to the virion. This antigen was found to be heat stable and trypsin resistant.

A "soluble" CF antigen has been reported for MHV (CALISHER and RowE, 1966). Detailed information on the nature of this antigen is, however, not available. The $\mathrm{CF}$ antigen from human strain $\mathrm{OC} 43$ has been more extensively studied. It appears to be attached to the virion in such a way that, unlike that of myxoviruses, it is not liberated by ether or ether-tween treatment (KAYE et al., 1970). HIERHOLZER et al. (1972) were able to remove all CF activity from purified OC43 virions by treatment with bromelin. The same treatment removed the projections and destroyed both $\mathrm{HA}$ activity and infectivity. The $\mathrm{CF}$ antigen, like the $\mathrm{HA}$ antigen, was relatively resistant to heat $\left(56^{\circ} \mathrm{C}\right.$ for 30 minutes).

\section{Serologic Interrelationships Among Coronaviruses}

Coronaviruses, as a group, display complex serologic variability. This variability has apparently resulted in interrelationships, more or less close, between different strains from the same host species, as well as between strains from different host species. The full picture of these interrelationships is not yet complete, but certain generalizations are warranted. The details of these complex problems are published in recent papers by DAwson et al. (1971), Bradburne (1970), and McIntosh et al. (1969).

The TGEV strains appear to be unique among the coronaviruses in that no antigenic diversity between strains has yet been demonstrated (BOHL and Kumagar, 1965; SASAhara et al., 1958; CarTWRight, 1966; LeE et al., 1954; RisTIC et al., 1965). Interrelationships between TGEV strains and HEV strains have been briefly explored in a study reported by PHILlIP et al. (1971). A precipitation arc of identity between the two viruses was described, despite the lack of an antigenic relationship in reciprocal neutralization tests. The possibility of an interrelationship between TGEV and IBV is suggested by the finding that TGEV-coated bentonite particles were flocculated by a chicken antiserum against IBV (strain not specified) at a dilution of $1: 80$ (SiBINovic et al., 1966). Hyperimmune animal sera against 21 other viruses, including a chicken serum prepared against fowlpox, failed to flocculate the particles at dilutions greater than $1: 20$, and the homologous swine serum flocculated to a dilution of $1: 320$. This intriguing finding has not been explored further.

Also of interest is the presence of moderately high titers of neutralizing antibody to TGEV in dogs (Norman et al., 1970). Antibodies were found in dogs with no exposure to pigs, although they were not present in animals raised in a closed colony. This finding suggests the possible existence of a canine coronavirus related to TGEV. Antibodies to TGEV in human sera have not been sought. 
On the basis of evidence available to date, IBV appears to be a serologically isolated species: attempts to show relationships between various strains of IBV and other coronaviruses (aside from the brief reference to a possible relation with TGEV mentioned in the previous section) have been uniformly unsuccessful (BRADBuRne, 1970; McIntosh et al., 1969). Neutralizing antibodies to IBV strain 41 have been found in human sera (Miller and YATES, 1968), but exclusively in individuals with close and repeated contacts with chickens. Such antibodies are probably stimulated by exposure to virus aerosols, either from vaccines or from wild virus, and do not necessarily imply that IBV can replicate in man or that a human coronavirus antigenically related to IBV-41 exists. Indeed, the results of more direct studies of known human strains (BRADBURNE, 1970; MCINTOSH et al., 1969) would imply that this was not so. Nevertheless, conclusive evidence of the serologic isolation (or lack thereof) of IBV must await more sophisticated studies of antigenic relationships within the group itself.

In spite of their isolation, however, the various strains of IBV appear to be closely interrelated one with another and form a highly complex and confusing antigenic pattern. All strains of IBV may well be interrelated through the common precipitating antigen described by BERRY and STOKES (1968). However, other serologic techniques, namely neutralization tests in embryonated eggs or tissue culture, cross-protection studies in chickens, and fluorescent antibody studies, show an exceedingly complex picture (Cook, 1968; Hitchner et al., 1966; Hopkins, 1969; LUCIO and HitchNer, 1970; Winterfield et al., 1971; Dawson and Gough, 1971; Hofstad, 1958; Hofstad, 1961; Lukert, 1969; Cowen et al., 1971 a; RAGGI and LEE, 1957; WINTERFIELD et al., 1964). Interrelationships have been frequently demonstrated by one technique and not by another, so that a satisfactory over-all scheme cannot be constructed. The problem is an important one, since poultry farmers depend on IBV vaccines to protect their flocks. Moreover, although there are between seven and fifteen well recognized different serotypes, most vaccines contain only two, namely the Massachusetts and Connecticut strains (Cunningham, 1970). This is because, in practice, many strains show interrelationships by cross-protection studies, even though more discriminating tests demonstrate marked differences. It is clear that some systematic effort must be made to obtain plaque-purified strains, to perform tests with standardized sera, and to work, in cross-challenge tests, with virus-free flocks under tightly controlled conditions. It is only through an effort such as this that the picture will be clarified.

It is not unlikely that a complex picture similar to that described above exists for both MHV and the human coronaviruses. Detailed reports of MHV serologic studies are not published. However, those data which are available show that all known strains of MHV are interrelated, either in CF tests or in neutralization tests, although no two strains appear exactly alike (CALISHER and Rowe, 1966; Morris, 1959; Starr and Pollard, 1959a; Manaker et al., 1961; Dick et al., 1956; GLedHILl and Niven, 1955; MorRis et al., 1966). 
MHV, unlike IBV, is serologically related to coronaviruses from animal species other than the mouse. Several strains are closely related to RCV and SDAV by CF tests and distantly related to RCV by cross-neutralization tests (PARKer et al., 1970; BhATt et al., 1972). Likewise, several strains of MHV are closely related to human coronaviruses OC38 and OC43 (McInTosh et al., 1967 a) ; MHV-3 has also been shown to be related to strain 229E (BRADBURNE 1970). Antibody to several strains of MHV is commonly found in human sera, probably because of endemic human infection with related coronaviruses (HARTLEY et al., 1964).

The human coronaviruses are similarly complex. The strains which were primarily isolated in tissue culture monolayers form a fairly homogenous group whose members are similar or identical to strain 229E (HAMrE and PRocknow, 1966; KAPIKIAN et al., 1969). However, one strain, LP, was originally isolated in HETOC, resembles $229 \mathrm{E}$ quite closely, but differs from it by neutralization kinetics (BRADBURNE, 1970). Other organ culture isolated strains are more heterogenous. The two viruses which were adapted to grow in suckling mouse brain, strains OC38 and OC43, are probably identical (McINTOSH et al., 1967a), and another strain OC44, is quite similar (McINTosH et al., 1969). All three are closely related by CF tests to MHV. But other strains, including B814, EVS, OC16, OC37 and OC48 are poorly characterized and variably related to each other, strains $229 \mathrm{E}$ and OC38-43, and MHV. It is not unlikely that strain OC38-43 is related, although distantly, to 229E (BRADBURNE, 1970).

\section{Summary}

This review has concentrated primarily on the comparative aspects of coronavirus virology. It is clear that all of the coronavirus species share certain biophysical and chemical characteristics: in negatively stained preparations their size is $80-160 \mathrm{~nm}$, and particles are round, moderately pleomorphic, and covered with widely spaced, $20 \mathrm{~nm}$ club-shaped projections; in ultrathin sections they are 75-90 $\mathrm{nm}$ in diameter, and possess an outer membrane and an inner shell; their nucleic acid type is RNA; they are ether and chloroform labile; and their buoyant density in sucrose is $1.18-1.19 \mathrm{gms} / \mathrm{cu} . \mathrm{cm}$. Some of the species (and, perhaps, types) differ in their sensitivity to acid $\mathrm{pH}$ and trypsin. As far as is presently known, the ultrastructural morphogenesis of all species is similar, although perhaps not identical. Two coronavirus species hemagglutinate; the rest apparently do not. The antigenic characteristics of the various species vary widely: TGEV shows little or no variation between strains; MHV and IBV show an apparently limitless antigenic variability between strains, and the HCV types probably resemble MHV and IBV. Some coronavirus species are extremely fastidious in their in vitro growth requirements and others are considerably less so.

As a virus genus, the coronaviruses are of great economic importance. They are the cause of several animal diseases of world-wide distribution and high 
morbidity and mortality. In man they are responsible for a significant proportion of upper respiratory illness and are major contributors to economic loss due to sick leave. Further investigation into their properties is clearly indicated.

Studies of the biophysical and chemical nature of coronavirus virions have lagged behind other types of research and deserve to be pursued now. These include an examination of purification methods for all the coronavirus species, and chemical and physical characterization of the nucleic acid, core and envelope. The molecular events in coronavirus infected cells have not been examined to any significant extent. The genetics of coronaviruses have been similarly neglected and are particularly important in those species which show marked and complex antigenic variation.

One of the attractive features of coronavirus research is the intriguing possibility that discoveries in one species may have application in another. Thus, examination of the nature of virus-cell interaction of some less fastidious coronavirus species, such as MHV, may elucidate factors leading to more successful cultivation of human strains. Already the necessary use of the electron microscope in the study of HCV strains has led to more rapid and precise virologic diagnosis in IBV infection. Such interplay between veterinary and human virology was the object of a recent coronavirus workshop (Anonymous, 1972) and should be encouraged.

Other areas of research, though perhaps more mundane, are not less important. IBV serology, like HCV serology, is of great practical importance and should receive due emphasis. Some of the inter-species antigenic relationships, particularly those involving the porcine coronaviruses, should be explored. Coronaviruses should be sought in other animal species. And, finally, efforts to attenuate coronaviruses should be systematically pursued, since effective vaccines, particularly for IBV and TGEV, are clearly of paramount importance.

Acknowledgements. Mrs. J. H. DeEs assisted in preparing Figs. 1-8 and 11-13, and Mrs. J. D. Almeida generously supplied Figs. 9 and 10. Mrs. Linda Coleman furnished valuable secretarial help. I am profoundly grateful to Dr. RoBERT CHANOck for engendering and fostering my interest in coronaviruses, and to Dr. D. A. J. Tyrell for advice and assistance in preparing this manuscript.

\section{References}

Akers, T. G., Cunningham, C. H.: Replication and cytopathogenicity of avian infectious bronchitis virus in chicken embryo kidney cells. Arch. ges. Virusforsch. 25, 30-37 (1968).

Almeida, J. D., Tyrrell, D. A. J.: The morphology of three previously uncharacterized human respiratory viruses that grow in organ culture. J. gen Virol. 1, 175-178 (1967).

Anonymous: Workshop on coronaviruses. J. infect. Dis. 126, 114-115 (1972).

Apostolov, K., Flewett, T. H., Kendal, A. P.: In: The biology of large RNA viruses. Barry, R. D. \& Mahy B. W. J., eds., p. 3-26. London. Academic Press 1970.

BÄHR, K. H.: Identification of transmissible porcine gastroenteritis in Germany. Dtsch. tierärztl. Wschr. 76, 509-514 (1969).

Bailey, O. T., Pappenheimer, A. M., Cheever, F. S., Daniels, J. B.: A murine virus ( JHM) causing disseminated encephalomyelitis with extensive destruction of myelin. II. Pathology. J. exp. Med. 90, 195-212 (1949). 
BANG, F. B., WARwick, A.: Mouse macrophages as host cells for the mouse hepatitis virus and the genetic basis of their susceptibility. Proc. nat. Acad. Sci. (Wash.) 46, 1065-1075 (1960).

Barinsky, I. F.: Species insusceptibility in viral hepatitides. Acta virol. 11, 483 (1967).

Barinsky, I. F., Dementiev, I. V.: Virological and cytogenetic studies on the involvement of the bone marrow of mice in some hepatoencephalotropic viral infections. Acta virol. 12, 464-467 (1968).

Beach, J. R., Schalm, O. W.: A filterable virus, distinct from that of laryngotracheitis, the cause of a respiratory disease of chicks. Poultry Sci. 15, 199-206 (1936).

Beaudette, F. R., Hudson, C. B.: Cultivation of the virus of infectious bronchitis. J. amer. vet. med. Ass. 90, 51-60 (1937).

Becker, W. B., McIntosh, K., Dees, J. H., Chanock, R. M.: Morphogenesis of avian infectious bronchitis virus and a related human virus (strain 229E). J. Virol. 1, 1019-1027 (1967).

BERRY, D. M.: Intracellular development of infectious bronchitis virus. Nature (Lond.) 216, 393-394 (1967).

Berry, D. M., Almeida, J. D.: The morphological and biological effects of various antisera on avian infectious bronchitis virus. J. gen. Virol. 3, 97-102 (1968).

Berry, D. M., Cruickshank, J. G., Chu, H. P., Wells, R. J. H.: The structure of infectious bronchitis virus. Virology 23, 403-407 (1964).

Berry, D. M., Stokes, K. J.: Antigenic variations in isolates of infectious bronchitis virus. Vet. Rec. 82, 157-160 (1968).

Bhatt, P. N., PeRCy, D. H., JonAs, A. M.: Characterization of the virus of sialodacryoadenitis of rats: A member of the coronavirus group. J. infect. Dis. 126, 123-130 (1972).

Biggart, J. D., RuebneR, B. H.: Lymphoid necrosis in the mouse spleen produced by mouse hepatitis virus (MHV3): an electron microscopic study. J. med. Microbiol. 3, 627-632 (1970).

Biswal, N., Nazerian, K., Cunningham, C. H.: A hemagglutinating fraction of infectious bronchitis virus. Amer. J. vet. Res. 27, 1157-1167 (1966).

Bito, Y., Hironao, T., Masui, T.: Preliminary studies on diagnosis of avian infectious bronchitis by fluorescent antibody technique. Jap. J. vet. Sci. 33, 61-67 (1971).

BoHL, E. H.: Immunologic studies on transmissible gastroenteritis of swine. Proc. 18th World Vet. Cong., p. 577 (1967).

BoHL, E. H.: Transmissible gastroenteritis. In: Diseases of swine (H. W. Dunne, ed.), 3rd ed., p. 158-176. Iowa State Univ. Press 1970.

BoHL, E. H., KumagaI, T.: The use of cell cultures for the study of transmissible gastroenteritis virus of swine. Proc. 69th Annual Meeting, U. S. Livestock San. Ass., p. 343-350 (1965).

BRAdBURne, A. F.: Sensitivity of L132 cells to some "new" respiratory viruses. Nature (Lond.) 221, 85-86 (1969).

Bradburne, A. F.: Antigenic relationships amongst coronaviruses. Archiv. ges. Virusforsch. 31, 352-364 (1970).

Bradburne, A. F., Bynoe, M. L., Tyrrell, D. A. J.: Effects of a "new" human respiratory virus in volunteers. Brit. med. J. 1967, 767-769.

Bradburne, A. F., Tyrrell, D. A. J.: The propagation of "coronaviruses" in tissueculture. Arch. ges. Virusforsch. 28, 133-150 (1969).

Bradburne, A. F., Tyrrell, D. A. J.: Coronaviruses of man. Progr. med. Virol. 13, 373-403 (1971).

Bradfute, O. E., Bohl, E. H., Harada, K.: Quoted in Diseases of swine (Howard Dunne, ed.), p. 161. 3rd ed. Iowa State Univ. Press 1970.

Braune, M. O., Gentry, R. F.: Standardization of the fluorescent antibody technique for the detection of avian respiratory viruses. Av. Dis. 9, 535-545 (1965).

Brown, W. E., Schmittle, S. C., Foster, J. W.: A tannic acid modified HA test for infectious bronchitis of chickens. Av. Dis. 6, 99-106 (1962).

BRŮČKovÁ, M., McIntosh, K., Kapikian, A. Z., ChANOCK, R. M.: The adaptation of two human coronavirus strains (OC 38 and $\mathrm{OC} 43)$ to growth in cell monolayers. Proc. Soc. exp. Biol. (N. Y.) 135, 431-435 (1970).

Bucknall, R. A., Kalica, A. R., Chanock, R. M.: Intracellular development and mechanism of hemadsorption of a human coronavirus, OC 43. Proc. Soc. exp. Biol. (N. Y.) 139, 811-817 (1972a). 
Bucknall, R. A., King, L. M., Kapikian, A. Z., Chanock, R. M.: Studies with numan coronaviruses, II. Some properties of strains 229E and OC 43. Proc. Soc. exp. Biol. (N. Y.) 139, 722-727 (1972b).

BüLow, V. voN: Infectious avian bronchitis: I. Virus cultivation in chick embryo kidney cells. Zbl. Vet.-Med. 13B, 345-363 (1966).

BüLOw, V. voN: Infectious bronchitis of chickens. IV. Characterization of a new field strain of infectious bronchitis virus (IBV-10). Zbl. Vet.-Med. 14B, 151-162 (1967).

Bülow, V. von, Schneider, L. G.: Fluoreszenzserologischer Nachweis des HühnerBronchitisvirus in Zellkulturen und Küken. Zbl. Vet.-Med. 16B, 10-23 (1969).

Butler, M. P.: Avian viruses in adult cells in vitro. Virology 25, 454-468 (1965).

Calettr, E., Ristic, M., Ferris, D. H.: Etiologic studies of transmissible gastroenteritis of swine. Amer. J. vet. Res. 31, 2013-2017 (1970).

Caletti, E., Ristic, M., Lehmden-Maslin, A. A. von: Serologic detection of a virus of transmissible gastroenteritis of swine and determination of its nucleic acid type. Amer. J. vet. Res. 29, 1603-1612 (1968).

Calisher, C. H., Rowe, W. P.: Mouse hepatitis, Reo-3 and the Theiler viruses. Nat. Cancer Inst. Monogr. No 20, 67-75 (1966).

CARTwright, S. F.: A cytopathic virus causing a transmissible gastroenteritis in swine. II. Biological and serological studies. J. comp. Path. 76, 95-106 (1966).

Cartwright, S. F., Harris, H. M., Blandford, T. B., Fincham, I., Gitter, M.: Transmissible gastroenteritis of pigs. Vet. Rec. 76, 1332-1333 (1964).

Cartwright, S. F., Harris, H. M., Blandford, T. B., Fincham, I., Gitter, M.: A cytopathic virus causing a transmissible gastroenteritis in swine. I. Isolation and properties. J. comp. Path. 75, 387-396 (1965).

CARTWRIGHT, S. F., LuCAS, M.: Vomiting and wasting disease of piglets. Vet. Rec. 86, 278-280 (1970).

Cartwright, S. F., Lucas, M., Cavill, J. P., Gush, A. F., Blandford, T. B.: Vomiting and wasting disease of piglets. Vet. Rec. 84, 175-176 (1969).

Cavallaro, J. J., Monto, A. S.: Community-wide outbreak of infection with a $229 \mathrm{E}-$ like coronavirus in Tecumseh, Michigan. J. infect. Dis. 122, 272-279 (1970).

Chandler, R. L., Derbyshire, J. B., Smith, K.: Observations on the experimental infectivity and cellular pathology of transmissible gastroenteritis in piglets. Res. Vet. Sci. 10, 435-439 (1969).

Chany, C.: Enhancing effect of the Sarcoma virus in the replication of the mouse hepatitis virus in vitro. Proc. Soc. exp. Biol. (N. Y.) 131, 30-35 (1969).

Cheever, F. S., Daniels, J. B., Pappenheimer, A. M., Bailey, O. T.: A murine virus ( JHM) causing disseminated encephalomyelitis with extensive destruction of myelin. I. Isolation and biologic properties of the virus. J. exp. Med. 90, 181-194 (1949).

Chomiak, T. W., Luginbuhl, R. E., Jungherr, E. L.: The propagation and cytopathogenic effect of an egg-adapted strain of infectious bronchitis virus in tissue culture. Av. Dis. 11, 456-465 (1958).

Chubb, R. C., Cumming, R. B.: The use of the gel diffusion precipitin technique with avian infectious bronchitis nephritis virus. Aust. vet. J. 47, 496-499 (1971).

Churchill, A. E.: The use of chicken kidney tissue culture in the study of the avian viruses of Newcastle disease, infectious laryngotracheitis and infectious bronchitis. Res. Vet. Sci. 6, 162-169 (1965).

Clarke, J. K., McFerran, J. B., Gay, F. W.: Use of allantoic cells for the detection of avian infectious bronchitis virus. Arch. ges. Virusforsch. 36, 62-70 (1972).

Colwell, W. M., Lukert, P. D.: Effects of avian infectious bronchitis virus (IBV) on tracheal organ cultures. Av. Dis. 13, 888-894 (1969).

Compans, R. W., Klenk, H. D., Caliguiri, L. A., Choppin, P. W.: Influenza virus proteins. I. Analysis of polypeptides of the virion and identification of spike glycoproteins. Virology 42, 880-889 (1970).

Cоок, J. K. A.: Duration of experimental infectious bronchitis in chickens. Res. Vet. Sci. 9, 506-514 (1968).

Corbo, L. J., Cunningham, C. H.: Hemagglutination by trypsin-modified infectious bronchitis virus. Amer. J. vet. Res. 20, 876-883 (1959).

Cowen, B. S., Hitchner, S. B., Lucio, B.: Characterization of a new infectious bronchitis virus isolate. I. Serological and pathogenicity studies of Clark 333. Av. Dis. 15, 518-526 (1971 a). 
Cowen, B. S., Hitchner, S. B., Ubertini, T.: Characterization of a new infectious bronchitis virus isolate. II. Some chemical and physical properties of Clark 333. Av. Dis. 15, 527-532 (1971 b).

Cuccurullo, L., Piazza, M.: Osservazioni al microscopio elettronico di tessuti di topi infettati von virus epatico MHV-3. II. Alterazioni spleniche. Riv. Anat. pat. 26, 231-242 (1964).

Cunningham, C. H.: Avian infectious bronchitis. Advanc. vet. Sci. Comp. Med. 14, 105-148 (1970).

Cunningham, C. H., Spring, M. P.: Some studies of infectious bronchitis virus in cell culture. Av. Dis. 9, 182-193 (1965).

Cunningham, C. H., Stuart, H. O.: The effect of certain chemical agents on the virus of infectious bronchitis of chickens. Amer. J. vet. Res. 7, 466-469 (1946).

Datta, D. V., Isselbacher, K. J.: Effect of corticosteroids on mouse hepatitis virus infection. Gut 10, 522-529 (1969).

David-Ferreira, J. F., Manaker, R. A.: An electron microscope study of the development of a mouse hepatitis virus in tissue culture cells. J. Cell Biol. 24, 57-78 (1965).

Dawson, P. S., Gough, R. E.: Antigenic variation in strains of avian infectious bronchitis virus. Arch. ges. Virusforsch. 34, 32-39 (1971).

Dick, G. W. A., Niven, J. S. F., Gledhill, A. W.: A virus related to that causing hepatitis in mice (MHV). Brit. J. exp. Path. 37, 90-98 (1956).

DJurickovic, S., Thorsen, J.: Experimental immunization of sows against transmissible gastroenteritis. I. Immunization with a bacteria-free suspension of transmissible gastroenteritis virus prepared from the intestines of infected pigs. Vet. Rec. 87, 62-64 (1970).

Domermuth, C. H., Edwards, O. F.: An electron microscope study of chorioallantoic membrane infected with the virus of avian infectious bronchitis. J. infect. Dis.100, 74-81 (1957).

Doyle, L. P., Hutchings, L. M.: A transmissible gastroenteritis in pigs. J. Amer. vet. Ass. 108, 257-259 (1946).

Estola, T.: Studies on the infectious bronchitis virus of chickens isolated in Finland with reference to the serological survey of its occurrence. Acta vet. scand., Suppl. 18, 1-111 (1966).

Estola, T.: Sensitivity of suckling mice to various strains of infectious bronchitis virus. Acta vet. scand. 8, 86-87 (1967).

Estola, T., Weckstrom, P.: Electron microscopy of infectious bronchitis virus. Ann. Med. exp. Fenn. 45, 30-31 (1967).

Eto, M., Ichihara, T., Tsunoda, T., Watanabe, S.: Outbreaks of transmissible gastroenteritis among swine in the Kyushu region. J. Jap. vet. med. Ass. 15, 16-20 (1962).

FABRICANT, J.: Studies on the diagnosis of Newcastle disease and infectious bronchitis. IV. The use of the serum neutralization test in the diagnosis of infectious bronchitis. Cornell Vet. 41, 68-80 (1951).

Fahey, J. E., Crawley, J. F.: Propagation of infectious bronchitis virus in tissue culture. Canad. J. Microbiol. 2, 503-510 (1956).

FERRIS, D. H.: Epizootiologic features of transmissible gastroenteritis. J. Amer. vet. med. Ass. 159, 184-194 (1971).

Gallily, R., WARwick, A., BANG, F. B.: Effect of cortisone on genetic resistance to mouse hepatitis virus in vivo and in vitro. Proc. not. Acad. Sci. (Wash.) 51, 11581164 (1964).

Gallily, R., WARWICK, A., BANG, F. B.: Ontogeny of macrophage resistance to mouse hepatitis in vivo and in vitro. J. exp. Med. 125, 537-548 (1967).

Girard, A., Greig, A. S., Mitchell, D.: Encephalomyelitis of swine caused by a hemagglutinating virus. III. Serologic studies. Res. Vet. Sci. 5, 294-302 (1964).

GledHILl, A. W.: Enhancement of the pathogenicity of mouse hepatitis virus $\left(\mathrm{MHV}_{1}\right)$ by prior infection of mice with certain leukaemia agents. Brit. J. Cancer 15, 531-538 (1961).

GLEDHILL, A. W.: Viral diseases in laboratory animals. In: The problems of laboratory animal disease (R. J. C. Harris, ed.), p. 99-113, London: Academic Press 1962.

Gledhill, A. W., Andrewes, C. H.: A hepatitis virus of mice. Brit. J. exp. Path. 32, 559-568 (1951). 
Gledhill, A. W., Dick, G. W. A., Andrewes, C. H.: Production of hepatitis in mice by the combined action of two filterable agents. Lancet 1952 II, 509-511.

Gledhill, A. W., Niven, J. S. F.: Latent virus as exemplified by mouse hepatitis virus (MHV). Vet. Rev. Annot. 1, 82-90 (1955).

Gompels, A. E. H., Niven, J. S. F.: The propagation of $\mathrm{S}$ virus of mouse hepatitis in tissue culture. J. Path. Bact. 66, 567-569 (1953).

Goodwin, R. F. W., Jennings, A. R.: A highly infectious gastro-enteritis of pigs. Vet. Rec. 70, 271-272 (1958).

GREIG, A. S., Girard, A.: Encephalomyelitis of swine caused by a hemagglutinating virus. II. Virological studies. Res. Vet. Sci. 4, 511-517 (1963).

GREIG, A. S., GirARD, A.: Encephalomyelitis of swine caused by a hemagglutinating virus. V. Response to metabolic inhibitors and other chemical compounds. Res. Vet. Sci. 10, 509-513 (1969).

Greig, A. S., Mitchell, D., Corner, A. H., Bannister, G. L., Meads, E. B., Julian, R. J.: A hemagglutinating virus producing encephalomyelitis in baby pigs. Canad. J. comp. Med. 26, 49-56 (1962).

Haelterman, E. O.: Epidemiological studies of transmissible gastroenteritis of swine. Proc. U. S. Livestock San. Assn. 66, 305-315 (1962).

Haelterman, E. O., Hooper, B. E.: Transmissible gastroenteritis of swine as a model for the study of enteric disease. Gastroenterology 53, 109-113 (1967).

HAFF, R.: Plaque-formation by a mouse hepatitis virus. Virology 18, 507-508 (1962).

HAMre, D., BEEM, M.: Virologic studies of acute respiratory disease in young adults. V. Coronavirus 229E infections during six years of surveillance. Amer. J. Epidem. 96, 94-106 (1972).

Hamre, D., Kindig, D. A., Mann, J.: Growth and intracellular development of a new respiratory virus. J. Virol. 1, 810-816 (1967).

Hamre, D., Procknow, J. J.: A new virus isolated from the human respiratory tract. Proc. Soc. exp. Biol. (N. Y.) 121, 190-193 (1966).

Harada, K., Kaji, T., Kumagai, T., Sasahara, J.: Studies on TGE in pigs. IV. Physicochemical and biological properties of transmissible gastroenteritis virus. Nat. Inst. Anim. Hlth Quart. 8, 140-147 (1968).

Harada, K., Kumagai, T., Sasahara, J.: Cytopathogenicity of transmissible gastroenteritis virus in pigs. Nat. Inst. Anim. Hlth Quart. 3, 166-167 (1963).

Harada, K., Kumagai, T., Sasahara, J.: Studies on transmissible gastroenteritis in pigs. III. Isolation of cytopathogenic virus and its use for serological investigation. Nat. Inst. Anim. Hlth Quart. 7, 127-137 (1967).

Hartley, J. W., Rowe, W. P.: Tissue culture cytopathic and plaque assays for mouse hepatitis viruses. Proc. Soc. exp. Biol. (N. Y) 113, 403-406 (1963).

Hartley, J. W., Rowe, W. P., Bloom, H. H., Turner, H. C.: Antibodies to mouse hepatitis viruses in human sera. Proc. Soc. exp. Biol. (N. Y) 115, 414-418 (1964).

Hierholzer, J. C., Palmer, E. L., Whitfield, S. G., Kaye, H. S., Dowdle, W. R.: Protein composition of coronavirus OC 43. Virology 48, 516-527 (1972).

Hirai, K., Shimakura, S.: Isolation and characteristics of avian nephrosis-inducing infectious bronchitis virus (coronavirus). Jap. J. vet. Sci. 33, 209-216 (1971).

Hirano, T., Ruebner, B. H.: The effect of murine hepatitis virus infection on lymphatic organs. Lab. Invest. 14, 488-500 (1965).

Hironao, T., Masui, T., Bito, Y.: A soluble antigen of infectious bronchitis virus. Jap. J. Microbiol. 14, 495-500 (1970).

Hitchner, S. B., Winterfield, R. W., Appleton, G. S.: Infectious bronchitis virus types incidence in the United States. Av. Dis. 10, 98-102 (1966).

Hofstad, M. S.: A study of infectious bronchitis in chickens. IV. Further observations on the carrier status of chickens recovered from infectious bronchitis. Cornell Vet. 37, 29-34 (1947).

Hofstad, M. S.: Stability of avian infectious bronchitis virus at $56^{\circ} \mathrm{C}$. Cornell Vet. 46, 122-128 (1956).

Hofstad, M. S.: Antigenic differences among isolates of avian infectious bronchitis virus. Amer. J. vet. Res. 19, 740-743 (1958).

Hofstad, M. S.: Antigenic and immunological studies on several isolates of avian infectious bronchitis virus. Av. Dis. 5, 102-107 (1961). 
Hofstad, M. S.: Infectious bronchitis. In: Diseases of poultry, 5th ed., Biester, H. E. and Schwarte, L. H., eds., p. 605-619 Ames, Iowa: Iowa State Univ. Press 1965.

Hofstad, M. S., Yoder, H. W., JR.: Avian infectious bronchitis-virus distribution in tissues of chicks. Av. Dis. 10, 230-239 (1966).

Hooper, B. E., Haelterman, E. O.: Growth of transmissible gastroenteritis virus in young pigs. Amer. J. vet. Res. 27, 286-291 (1966).

Hopkins, S. R.: Serologic and immunologic properties of a recent isolate of infectious bronchitis virus. Av. Dis. 13, 356-362 (1969).

Hunstein, W.: Panmyelophthisis and viral hepatitis. Experimental study with the MHV 3. Acta. haemat. (Basel) 42, 336-346 (1969).

InNES, J. R., Stanton, M. F.: Acute diseases of the submaxillary and harderian glands (sialodacryoadenitis) of rats with cytomegaly and no inclusion bodies. Amer. J. Path. 38, 455-468 (1961).

Johnson, R. B., Newman, J. A., Wills, F. K.: Titration of infectious bronchitis virus in tracheas of susceptible and immune chickens. Av. Dis. 13, 632-635 (1969).

Jonas, A. M., Craft, J., Black, L., Bhatt, P. N., Hilding, D.: Sialodacryoadenitis in the rat. A light and electron microscopic study. Arch. Path. 88, 613-622 (1969).

Jungherr, E. L., Chomiak, T. W., Luginbuhl, R. E.: Immunologic differences in strains of infectious bronchitis virus. Proceedings of the 60th Ann. Meeting of the U. S. Livestock Sanitary Assoc., Chicago. Ill. p. 203-209 (1956).

Jungherr, E. L., TERrell, N. L.: Naturally acquired passive immunity to infectious bronchitis in chicks. Amer. J. vet. Res. 9, 201-205 (1948).

Kantoch, M., BANG, F. B.: Conversion of genetic resistance of mammalian cells to susceptibility to a virus infection. Proc. nat. Acad. Sci. (Wash.) 48, 1553-1559 (1962).

Kapikian, A. Z., James, H. D., JR., Kelly, S. J., Dees, J. H., Turner, H. C., McIntosh, K., Kim, H. W., Parrott, R. H., Vincent, M. M., Chanock, R. M.: Isolation from man of "avian infectious bronchitis virus-like" viruses (coronaviruses) similar to $229 \mathrm{E}$ virus, with some epidemiological observations. J. infect. Dis. 119, 282-290 (1969).

Kapikian, A. Z., James, H. D., JR., Kelly, S. J., King, L. M., Vaughn, A. L., Chanock, R. M.: Hemadsorption by coronavirus strain OC43. Proc. Soc. exp. Biol. (N. Y.) 139, 179-186 (1972).

Kawamura, H., Isogai, S., Tsubahara, H.: Propagation of avian infectious bronchitis virus in chicken kidney tissue culture. Nat. Inst. Anim. Hlth Quart. 1, 190-198 (1961).

KaYe, H. S., Dowdle, W. R.: Some characteristics of hemagglutination of certain strains of "IBV-like" virus. J. infect. Dis. 120, 576-581 (1969).

Kaye, H. S., Hierholzer, J. C., Dowdle, W. R.: Purification and further characterization of an "IBV-like" virus (coronavirus). Proc. Soc. exp. Biol. (N. Y.) 135, 457-463 (1970).

Kaye, H. S., Marsh, H. B., Dowdle, W. R.: Seroepidemiologic survey of coronavirus (strain OC 43) related infections in a children's population. Amer. J. Epidem. 94, 43-49 (1971).

Kelly, M., Butler, D. G., Hamilton, J. R.: Transmissible gastroenteritis in piglets: A model of infantile viral diarrhea. J. Pediat. 80, 925-931 (1972).

Kendall, E. J. C., Bynoe, M. L., Tyrrell, D. A. J.: Virus isolations from common colds occurring in a residential school. Brit. med. J. 1962 II, 82-86.

Konishi, S., BANkowski, R. A.: Use of fluorescein-labeled antibodies for rapid diagnosis of transmissible gastroenteritis in experimentally infected pigs. Amer. J. vet. Res. 28, 937-942 (1967).

Kumar, P. N.: Studies on infectious bronchitis of chicks. Indian J. Anim. Sci. 41, 490496 (1971).

LAUFS, R.: Studies on the development of giant cells in mouse macrophage cultures infected with MHV-3. Virchows Arch. path. Anat. 342, 169-183 (1967).

LAVElle, G. C., StaRr, T. J.: Relationship of phagocytic activity to pathogenecitiy in mouse hepatitis virus as affected by triolein and cortisone. Brit. J. exp. Path. 50, 475-480 (1969).

Laver, W. G., Kilbourne, E. D.: Morphology of the isolated hemagglutinin and neuraminidase subunits of influenza virus. Virology 38, 105-119 (1969).

LEE, K. M.: Propagation of transmissible gastroenteritis virus in tissue culture. Ann. N. Y. Acad. Sci. 66, 191-195 (1956). 
Lee, K. M., Moro, M., Baker, J. A.: Transmissible gastroenteritis in pigs. Amer. J. vet. Res. 15, 364-372 (1954).

Lucas, M. H., Napthine, P.: Fluorescent antibody technique in the study of three porcine viruses: transmissible gastroenteritis virus. vomiting and wasting disease virus and the parvovirus 59E-63. J. comp. Path. 81, 111-117 (1971).

Lucio, R., Hitchner, S. B.: Differentiation and detection of the infectious bronchitis virus subtypes by immunofluorescence. Av. Dis. 14, 9-23 (1970).

Lukert, P. D.: Comparative sensitivities of embryonating chicken's eggs and primary chicken embryo kidney and liver cell cultures to infectious bronchitis virus. Av. Dis. 9, 308-316 (1965).

LUKERT, P. D.: Immunofluorescence of avian infectious bronchitis virus in primary chicken embryo kidney, liver, lung and fibroblast cell cultures. Arch. ges. Virusforsch. 19, 265-272 (1966).

LukERT, P. D.: Differentiation of avian infectious bronchitis virus serotypes by immunofluorescence. Av. Dis. 13, 847-852 (1969).

MalluccI, L.: Observations on the growth of mouse hepatitis virus (MHV-3) in mouse macrophages. Virology 25, 30-37 (1965).

Manaker, R. A., Piczak, C. V., Miller, A. A., Stanton, M. F.: A hepatitis virus complicating studies with mouse leukemia. Journal of the nat. Cancer Inst. 27, 29-45 (1961).

Manso, C., Friend, C., Wroblewski, F.: The influence of 17-hydroxycorticosterone on viral hepatitis of mice. J. Lab. clin. Med. 53, 729-736 (1959).

Marsolais, A., Berthiaume, L., Difranco, E., Marois, P.: Rapid diagnosis by electron microscopy of avian coronavirus infection. Canad. J. comp. Med. 35, 285-288 (1971).

MCClURKIN, A. W.: Studies on transmissible gastroenteritis of swine. I. Isolation and identification of a cytopathogenic virus of transmissible gastroenteritis in primary swine kidney cell cultures. Canad. J. comp Med. 29, 46-53 (1965).

McClurkin, A. W., Norman, J. O.: Studies of transmissible gastroenteritis of swine. II. Selected characteristics of a cytopathogenic virus common to five isolates from transmissible gastroenteritis virus. Canad. J. comp. Med. 30, 190-198 (1966).

McClurkin, A. W., Norman, J. O.: Studies on transmissible gastroenteritis of swine. III. The effect of selective inhibitors of viral replication on a cytopathogenic virus from transmissible gastroenteritis. Canad. J. comp. Med. 31, 299-302 (1967).

McDougall, J. S.: Infectious bronchitis in laying fowls. Its effect upon egg production and subsequent egg quality. Vet. Rec. 83, 84-86 (1968).

McFerran, J. B., Gordon, W. A. M., Taylor, S. M., McParland, P. J.: Isolation of viruses from 94 flocks of fowls with respiratory disease. Res. Vet. Sci. 12, 565-569 (1971).

McIntosh, K., Becker, W. B., Chanock, R. M.: Growth in suckling mouse brain of "IBV-like" viruses from patients with upper respiratory tract disease. Proc. nat. Acad. Sci. (Wash.) 58, 2268-2273 (1967a).

McIntosh, K., Dees, J. H., Becker, W. B., Kapikian, A. Z., Chanock, R. M.: Recovery in tracheal organ cultures of novel viruses from patients with respiratory disease. Proc. nat. Acad. Sci. (Wash.) 57, 933-940 (1967 b).

McIntosh, K., Ellis, E. F., Hoffman, L. S., Lybass, T. G., Eller, J. J., Fulginiti, V. A.: The association of viral and bacterial respiratory infections with exacerbations of wheezing in young asthmatic children. J. Pediat. 82, 578-593 (1973).

McIntosh, K., Kapikian, A. Z., Hardison, K. A., Hartley, J. W., Chanock, R. M.: Antigenic relationships among the coronaviruses of man and between human and animal coronaviruses. J. Immunol. 102, 1109-1118 (1969).

McIntosh, K., Kapikian, A. Z., Turner, H. C., Hartley, J. W., Parrott, R. H., Снanock, R. M.: Seroepidemiologic studies of coronavirus infection in adults and children. Amer. J. Epidem. 91, 585-592 (1970).

Mengeling, W. L., Boothe, A. D., Ritchie, A. E.: Characteristics of a coronavirus (strain 67 N) in pigs. Amer. J. vet. Res. 33, 297-308 (1972).

Miller, L. T., YATES, V. J.: Neutralization of infectious bronchitis virus by human sera. Amer. J. Epidem. 88, 406-409 (1968).

Mitchell, D.: Encephalomyelitis of swine caused by a haemagglutinating virus. I. Case histories. Res. Vet. Sci. 4, 506-510 (1963). 
Miyai, K., Slusser, R. J., Reubner, B. H.: Viral hepatitis in mice: an electron microscopic study. Exp. molec. Path. 2, 464-480 (1963).

Miyazaki, Y., Katsuta, H., Aoyama, Y., Kawai, K., Takaoka, T.: Experimental studies on hepatitis virus of mice in tissue culture. Jap. J. exp. Med. 27, 381-399 (1957).

Mohanty, S. B., Chang, S. C.: Development and ether sensitivity of infectious bronchitis virus of chickens in cell cultures. Amer. J. vet. Res. 24, 822-826 (1963).

Mohanty, S. B., Devolt, H. M., Faber, J. E.: A fluorescent antibody study of infectious bronchitis virus. Poultry Sci. 43, 179-182 (1964a).

Mohanty, S. B., Devolt, H. M., Faber, J. E.: A modified indirect hemagglutination test for infectious bronchitis of chickens. Amer. J. vet. Res. 25, 529-534 (1964b).

Morris, J. A.: A new member of hepatoencephalitis group of murine viruses. Proc. Soc. exp. Biol. (N. Y.) 100. 875-877 (1959).

Morris, J. A., PARker, J. C., Cross, S. S.: A serologic study of African epidemic icterus and murine hepatoencephalitis viruses. Fed. Proc. (abstracts) 25, 727 (1966).

Mosley, J. W.: Multiplication and cytopathogenicity of mouse hepatitis virus in mouse cell cultures. Proc. Soc. exp. Biol. 108, 524-529 (1961).

Mufson, M., McIntosh, K., Chao, R. K., Krause, H. E., Wasil, R., Mocega, H. E.: Epidemiology of coronavirus infections in infants with acute lower respiratory disease. Clin. Res. 20, 534 (1972).

Muldoon, R. L., Cunningham, C. H.: Some characteristics of the hemagglutinating activity of infectious bronchitis virus. Bact. Proc. 61, 157 (1961).

Nazerian, K., Cunningham, C. H.: Electron microscopy of the hemagglutinin of infectious bronchitis virus. Proceedings of the 25th Annual Electron Microscopy Society of America. 94-95 (1967).

Nazerian, K., Cunningham, C. H.: Morphogenesis of avian infectious bronchitis virus in chicken embryo fibroblasts. J. gen. Virol. 3, 469-470 (1968).

Nelson, J. B.: Acute hepatitis associated with mouse leukemia. I. Pathological features and transmission of the disease. J. exp. Med. 96, 293-302 (1952).

NeLson, J. B.: The enhancing effect of murine hepatitis virus on the cerebral activity of pleuropneumonia-like organisms in mice. J. exp. Med. 106, 179-191 (1957).

Niven, J. S. F., Gledhill, A. W., Dick, G. W. A., Andrewes, C. H.: Further light on mouse hepatitis. Lancet 1952 II, 1061.

Norman, J. O., McClurkin, A. W., Bachrach, H. L.: Infectious nucleic acid from a transmissible agent causing gastroenteritis in pigs. J. comp. Path. 78, 227-235 (1968).

Norman, J. O., McClurkin, A. W., Stark, S. L.: Transmissible gastroenteritis (TGE) of swine: canine serum antibodies against an associated virus. Canad. J. comp. Med. 34, 115-117 (1970).

Okaniwa, A., Harada, K., Park, D. K.: Structure of swine transmissible gastroenteritis virus examined by negative staining. Nat. Inst. Anim. Hlth Quart. 8, 175-181 (1968a).

Okaniwa, A., Maeda, M., Harada, K., Kaji, T.: Electron microscopy of swine transmissible gastroenteritis virus in tissue culture cells. Nat. Inst. Anim. Hlth Quart. 8, 148-163 (1968b).

Oshiro, L. S., Schieble, J. H., Lennette, E. H.: Electron microscopic studies of coronavirus. J. gen. Virol. 12, 161-168 (1971).

Page, C. A., Cunningham, C. H.: The neutralization test for infectious bronchitis virus. Amer. J. vet. Res. 23, 1065-1071 (1962).

PARAdisi, F.: Propagation of MHV-3 in monolayer cell cultures from liver of newborn mice. Experientia (Basel) 24, 373-374 (1968).

PARker, J. C., Cross, S. S., Rowe, W. P.: Rat coronavirus (RCV): A prevalent, naturally occurring pneumotropic virus of rats. Arch. ges. Virusforsch. 31, 293-302 (1970).

Pensaert, M. B.: Cell culture-adapted SH strain of transmissible gastroenteritis virus of pigs. Amer. J. vet. Res. 31, 771-781 (1970).

Pensaert, M., Haelterman, E. O., Burnstein, T.: Transmissible gastroenteritis of swine: virus-intestinal cell interactions. I. Immunoflourescence, histopathology and virus production in the small intestine through the course of infection. Arch. ges. Virusforsch. 31, 321-334 (1970a).

Pensaert, M., Haelterman, E. O., Hinsman, E. J.: Transmissible gastroenteritis of swine: virus-intestinal cell interactions. II. Electron microscopy of the epithelium in isolated jejunal loops. Arch. ges. Virusforsch. 31, 335-351 (1970 b). 
Phillip, J. I. H., Cartwright, S. F., Scott, A. C.: The size and morphology of transmissible gastroenteritis and vomiting and wasting disease viruses of pigs. Vet. Rec. 88, 311-312 (1971).

Piazza, M.: The fate of MHV-3 after intravenous injection into susceptible mice. Arch. ges. Virusforsch. 22, 472-474 (1967).

Piazza, M.: Experimental viral hepatitis. Springfield, Illinois: C. C. Thomas 1969.

PILCHARD, E. I.: Experimental transmission of transmissible gastroenteritis virus by starlings. Amer. J. vet. Res. 26, 1177-1179 (1965).

Quiroz, C. A., Hanson, R. P.: Physical-chemical treatment of inocula as a means of separating and identifying avian viruses. Av. Dis. 2, 94-98 (1958).

RAGGI, L. G., LEE, G. G.: Relationship between immunity and serum-neutralization titers in chickens inoculated with three infectious bronchitis vaccines. Amer. J. vet. Res. 18, 740-742 (1957).

Reagan, R. L., Brueckner, A. L.: Electron microscope studies of four strains of infectious bronchitis virus. Amer. J. vet. Res. 13, 417-418 (1952).

Reagan, R. L., Hauser, J. E., Lillie, M. G., Craige, A. H., Jr.: Electron micrograph of the virus of infectious bronchitis of chickens. Cornell Vet. 38, 190-191 (1948).

Ristic, M., Sibinovic, S., Alberts, J. O.: Electron microscopy and ether sensitivity of transmissible gastroenteritis virus of swine. Amer. J. vet. Res. 26, 609-616 (1965).

Roe, C. K., Alexander, T. J. L.: A disease of nursing pigs previously unreported in Ontario. Canad. J. comp. Med. 22, 305-307 (1958).

Rowe, W. P., Hartley, J. W., Capps, W. I.: Mouse hepatitis virus infection as a highly contagious, prevalent, enteric infection of mice. Proc. Soc. exp. Biol. (N. Y.) 112, 161-165 (1963).

Rubinstein, D., Tyrrell, D. A. J., Derbyshire, J. B., Collins, A. P.: Growth of porcine transmissible gastroenteritis virus in organ cultures of pig tissue. Nature (Lond.) 227, 1348-1349 (1970).

Ruebner, B. H., Bramhall, J. L.: Pathology of experimental virus hepatitis in mice. Arch. Path. 69, 190-198 (1960).

Ruebner, B. H., Hirano, T., Slusser, R. J.: Electron microscopy of the hepatocellular and Kupffer cell lesions of mouse hepatitis, with particular reference to the effect of cortisone. Amer. J. Path. 51, 163-190 (1967).

Sasahara, J., Harada, K., Hayashi, S., Watanabe, M.: Studies on transmissible gastroenteritis in pigs in Japan. Jap. J. vet. Sci. 20, 1-6 (1958).

Schalk, A. F., Hawn, M. C.: An apparently new respiratory disease of baby chicks. J. Amer. vet. med. Ass. 78, 413-422 (1931).

Seamer, J.: Mouse macrophages as host cells for murine viruses. Arch. ges. Virusforsch. 17, 654-663 (1965).

SheFFY, B. E.: Characterization of transmissible gastroenteritis virus. Proc. 69th Ann. Meeting of the U. S. Livestock San. Assoc., 351-363 (1965).

SHIF, I., BANG, F. B.: In vitro interaction of mouse hepatitis virus and macrophages from genetically resistant mice. I. Adsorption of virus and growth curves. J. exp. Med. 131, 843-850 (1970a).

SHIF, I., BANG, F. B.: In vitro interaction of mouse hepatitis virus and macrophages from genetically resistant mice. II. Biological characterization of a variant virus MHV $\left(\mathrm{C}_{3} \mathrm{H}\right)$ isolated from stocks of MHV (PRI). J. exp. Med. 131, 851-862 (1970b).

Sibinovic, K. H., Ristic, M., Sibinovic, S., Alberts, J. O.: Bentonite agglutination test for transmissible gastroenteritis of swine. Amer. J. vet. Res. 27, 1339-1344 (1966).

Simpson, R. W., Groupé, V.: Temperature of incubation as a critical factor in the behavior of avian bronchitis virus in chicken embryos. Virology 8, 456-469 (1959).

Starr, T. J., Pollard, M.: Complement fixation with tissue culture and liver antigens of mouse hepatitis. Nature (Lond.) 183, 1690-1691 (1959a).

Starr, T. J., Pollard, M.: Propagation of mouse hepatitis virus (Gledhill) in tissue culture. Proc. Soc. exp. Biol. (N. Y.) 100, 97-100 (1959b).

Starr, T. J., Pollard, M., Duncan, D., Dunaway, M. R.: Electron and fluorescence microscopy of mouse hepatitis virus. Proc. Soc. exp. Biol. (N. Y.) 104, 767-769 (1960).

Steele, F. M., Luginbuhl, R. E.: Direct and indirect complement fixation tests for infectious bronchitis virus. Amer. J. vet. Res. 25, 1249-1255 (1964). 
StĚPÁNeK, J., Pospíšil, Z., Mesároš, E.: Growth activity of transmissible gastroenteritis (TGE) virus in primary cultures of pig kidney cells and pig salivary gland cells. Acta vet. (Brno) 40, 235-240 (1971).

Stephens, P., Simmons. G. C.: Neutralising antibodies for avian infectious bronchitis virus in Queensland poultry flocks. Aust. vet. J. 44, 29-30 (1968).

Stinski, M. F., Cunningham, C. H.: Neutralizing antibody complex of infectious bronchitis virus. J. Immunol. 102, 720-727 (1969).

Sturman, L. S., TAKemoto, K. K.: Enhanced growth of a murine coronavirus in transformed mouse cells. Infect. and Immun. 6, 501-507 (1972).

Svoboda, D., Nielson, A., Werder, A., Higginson, J.: An electron microscopic study of viral hepatitis in mice. Amer. J. Path. 41, 205-224 (1962).

TAJIMA, M.: Morphology of transmissible gastroenteritis virus of pigs. Arch. ges. Virusforsch. 29, 105-108 (1970).

Tevethia, S. S., Cunningham, C. H.: Antigenic characterization of infectious bronchitis virus. J. Immunol. 100, 793-798 (1968).

Thake, D. C.: Jejunal epithelium in transmissible gastroenteritis of swine. Amer. J. Path. 53, 149-168 (1968).

Thorsen, J., DJuRIckovic, S.: Experimental immunization of sows with cell-cultured transmissible gastroenteritis virus. Canad. J. comp. Med. 34, 177-180 (1970).

Thorsen, J., DJuRIckovic, S.: Experimental immunization of sows with inactivated transmissible gastroenteritis virus. Canad. J. comp. Med. 35, 99-102 (1971).

Tisdale, W. A.: Potentiating effect of $\mathrm{K}$-virus on mouse hepatitis virus (MHV-S) in weanling mice. Proc. Soc. exp. Biol. (N. Y.) 114, 774-777 (1963).

Trentin, J. J., Hoosier, G. L. van, Shields, J., Stephens, K., Stenback, W. A., PARKer, J. C.: Limiting the viral spectrum of the laboratory mouse. Nat. Cancer Inst. Monograph No. 20, 147-160 (1966).

Tyrrell, D. A. J., Almeida, J. D., Berry, D. M., Cunningham, C. H., Hamre, D., Hofstad, M. S., Mallucci, L., McIntosh, K.: Coronaviruses. Nature (Lond.) 220, $650(1968 \mathrm{a})$.

Tyrrell, D. A. J., Bynoe, M. L.: Cultivation of a novel type of common-cold virus in organ cultures. Brit. med. J. 1, 1467-1470 (1965).

Tyrrell, D. A. J., Bynoe, M. L.: Cultivation of viruses from a high proportion of patients with colds. Lancet $1966 \mathrm{I}, 76-77$.

Tyrrell, D. A. J., Bynoe, M. L., Hoorn, B.: Cultivation of "difficult" viruses from patients with common colds. Brit. med. J. $1968 \mathrm{~b} \mathrm{I}, 606-610$.

UpPal, P. K., CHU, H. P.: An electron-microscope study of the trachea of the fowl infected with avian infectious bronchitis virus. J. med. Microbiol. 3, 643-647 (1970).

VaInıo, T.: Studies on murine hepatitis virus (MHV3) in vitro. Proc. Soc. exp. Biol. (N. Y.) 107, 326-331 (1961).

VAINIO, T., JUDAH, J. D.: Mechanism of cellular damage by virus: A study of antihistamine drugs. II. Murine hepatitis virus and mouse macrophages. Exp. molec. Path. 1, 27 (1962).

Van Roekel, H., Bullis, K. L., Clarke, M. K., Olesiuk, O. M., Sperling, F. G.: Infectious bronchitis. Massachusetts Agricultural Experiment Station Bull. No. $460,1950$.

Vella, P. P., Starr, T. J.: Effect of X-radiation and cortisone on mouse hepatitis virus infection in germ free mice. J. infect. Dis. 115, 271-277 (1965).

VetTerLein, W., LiebermanN, H.: The morphological development of the virus of transmissible gastroenteritis as compared to other viruses. Arch. exp. Vet.-Med. 24, 549-558 (1970).

WARD, J. M.: Morphogenesis of a virus in cats with experimental feline infectious peritonitis. Virology 41, 191-194 (1970).

Ward, J. M., Munn, R. J., Gribble, D. H., Dungworth, D. L.: An observation of feline infectious peritonitis. Vet. Rec. 416-417 (1968).

Watanabe, K.: Electron microscopic studies of experimental viral hepatitis in mice. I. Virus particles and their relationship to hepatocytes and Kupffer cells. J. Electron Micro. (Tokyo) 18, 158-172 (1969).

Welter, C. J.: TGE of swine. I. Propagation of virus in cell cultures and development of a vaccine. Vet. Med. Small Anim. Clin. 60, 1054-1058 (1965). 
Winterfield, R. W., Fadly, A. M., Hanley, J. E.: Characteristics of an isolate of infectious bronchitis virus from chickens in Florida. Av. Dis. 15, 305-311 (1971).

Winterfield, R. W., Hitchner, S. B.: Etiology of an infectious nephritis-nephrosis syndrome of chickens. Amer. J. vet. Res. 23, 1273-1279 (1962).

Winterfield, R. W., Hitchner, S. B., Appleton, G. S.: Immunological characteristics of a variant of infectious bronchitis virus isolated from chickens. Av. Dis. 8, 40-47 (1964).

WiтTE, K. H.: Isolation of the virus of transmissible gastroenteritis (TGE) from naturally infected piglets in cell culture. Zbl. Vet.-Med. 18B, 770-778 (1971).

WitTE, K. H., EAsterday, B. C.: Isolation and propagation of the virus of transmissible gastroenteritis of pigs in various pig cell cultures. Arch. ges. Virusforsch. 20, 327-350 (1967).

Witte, K. H., Tajima, M., Easterday, B. C.: Morphologic characteristics and nucleic acid type of transmissible gastroenteritis virus of pigs. Arch. ges. Virusforsch. 23, 53-70 (1968).

WitTeR, R. L.: The diagnosis of infectious bronchitis of chickens by the agar gel precipitin test. Av. Dis. 6, 478-492 (1962).

Woernle, H.: Diagnose der Infektiosen Bronchitis der Hühner mit Hilfe der Präzipitationsreaction im festen Agarmedium. Mh. Tierheilk 11, 154-167 (1959).

WoERnle, H.: The use of the agar-gel diffusion technique in the identification of certain avian virus diseases. Veterinarian 4, 17-28 (1966).

Wright, B. S., SAGIK, B. P.: Plaque formation in monolayers of chicken embryo kidney cells. Virology 5, 573-574 (1958). 